\title{
Possible Ameliorative Effect of Antioxidant (Taurine) in Pregnant Toxemic Female Rats
}

\author{
Ibrahim M.A. El-Agousa ${ }^{1}$, Dalia E. El-Nashar ${ }^{*}, 2$, Saad, S. Eissa ${ }^{3}$ and Mona N. Sharoud ${ }^{4}$ \\ ${ }^{I}$ Faculty of Science, Zoology Department, Cairo University, Egypt \\ ${ }^{2}$ Health Radiation Research, National Center for Radiation Research and Technology (NCRRT). Atomic Energy \\ Authority, Cairo, Egypt \\ ${ }^{3}$ National Cancer Institute, Cairo University, Egypt \\ ${ }^{4}$ Biological Application Department, Atomic Energy Authority, Cairo, Egypt
}

\begin{abstract}
The present study was designed to investigate the possible effects of the antioxidant taurine on pregnant adriamycin (ADR) induced toxemic female rats. ADR was injected intraperitoneally to 50 pregnant female rats (5 groups) to induce toxemia. the first is Frank control group injected only with saline; the second group is the Taurine group that determined the effect of taurine alone; the third group is the Toxemic group that showed the toxicity of Adriamycin; the fourth group is the Therapeutic group (Adriamycin followed by Taurine) and the fifth group is the Protective group (Taurine followed by Adriamycin) that showed the amelurative effect of taurine in these groups.

Blood pressure, liver and kidney function, lipid profile, taurine concentration in plasma, serum cortisone, T3 \&T4 were measured for all animals. Furthermore, histopathological examination and morphometric study for liver, kidney and cardiac muscle were done for all groups.

The results showed that, the Protective group has marked improvement in most biochemical parameters than the Therapeutic group compared to Toxemic group.

Morphometric study revealed a significant decrease in the nuclear area in the tissues of toxemic rats. Also, marked disturbances were observed in the histopathological architecture of the kidney, liver and heart in all toxemic rats. However, a marked improvement in morphometrical parameters and histopathological architecture was observed in protective group. The results support the ameliorative effect of taurine in the protection against toxemia during pregnancy in experimental animals.
\end{abstract}

Keywords: Hypertension, pregnant toxemia, antioxidant taurine.

\section{INTRODUCTION}

Hypertension is a common problem facing pregnant females today. Because high blood pressure is a major risk for heart attack since it causes damage to the blood vessels, heart, kidney, eyes and other organs [1]. So, hypertension (high blood pressure), is a condition commonly associated with narrowing of the arteries. This causes blood to be pumped with excessive force against the artery walls. It is called " Silent killer" because most people have no reason to think they might be hyper tensive [2].

Toxemia during pregnancy, or the so-called pregnancy induced hypertension (PIH), is a challenging clinical state, which complicates approximately $10 \%$ of all pregnancies. PIH remains a major cause of morbidity and mortality for both mother and fetus [3].

Recently, the multisystem nature of this unique gestational disorder has been emphasized. But widespread

*Address correspondence to this author at the Department of Health Radiation Research, National Center for Radiation and Technology, 3 Ahmed El Zumor St. , $8^{\text {th }}$ sector, Madinat Nasr, Cairo, Egypt;

E-mail: daliaessamy@yahoo.com vascular endothelial dysfunction and vasospasm, considered as one of the basics pathophysiology of this syndrome $[4,5]$.

Adriamycin is one of the chemotherapeutic drugs that are given as treatment for many forms of cancers, but unfortunately it has many side effects [6]. Special attention must be given to the nephrotoxicity persuaded by adriamycin that results in hypertension.

Taurine is a major free intracellular amino acid present in many tissues, and now it has been shown to be involved in many important physiological functions in the development of the CNS [7]; maintaining the structural integrity of the cell membrane [8], regulating $\mathrm{Ca}^{++}$binding and transport $[9$, 10] specially in cardiac muscle [11]; as an osmolyte [12, 13] and neurotransmitter $[14,15]$. In the last decade it has been proved that taurine plays an important role in protecting liver [16-19] kidney tissues [20-23] and cardiac muscle [11]; from different hepatotoxic, nephrotoxic and cardiotoxic substances in addition to well established hypolipidemic [24-26] and hypoglycemic effects [27-30].

The target of the present investigation was to visualize the possible effects of antioxidant (taurine) in pregnant adriamycin (ADR) induced toxemia in female rats. The 
results of which could direct the attention to the management of toxemia during pregnancy, which remains a major challenge of gynecologists.

\section{MATERIAL AND METHODS}

One hundred virgin female albino rats (Rattus rattus), 1012 weeks old body weight between 140-160 gm were randomly selected from a large population of animals. The animals were fed on a standard laboratory rodent diet (NRC) and fresh tap water.

The estrus phase was tested by vaginal smear from virgin females. Mating was allowed at a ratio of one male to three female rats in every cage during the estrus phase. The detection of pregnancy was carried out by the two following methods, and animals were considered pregnant when both methods confirmed positive results.

i. The vaginal smear method: A vaginal smear was spread on a glass slide with a drop of distilled water, and then dried in air. The dried smear was stained by hematoxylin $0.2 \%(0.2 \mathrm{gm}$ hematoxylin dissolved in $100 \mathrm{ml}$ distilled water), dried in air and examined microscopically for sperm detection.

ii. The vaginal plug method: The presence of a plug in the vagina confirmed the occurrence of mating and was recorded as the first day of gestation.

The pregnant rats were classified into five groups (ten animals each):

Group I (control group): pregnant rats were given only saline all through the gestation period.

Group II (Taurine group): pregnant rats were daily injected intraperitoneally (i.p) with $500 \mathrm{mg} / \mathrm{Kg}$ B.wt. taurine, all through the gestation period (about $23 \pm 2$ days).

Group III (Toxemic pregnant group): pregnant rats were daily injected (i.p) with cumulative dose of adriamycin (10mg/Kg B.wt.), which divided into 6 equal injections over a period of two weeks according to the method of Podjarny [31].

Group IV (Therapeutic group): pregnant rats were injected with Adriamycin and after two days taurine was administered.

Group V (Protective group): pregnant rats were injected with ADR, but 2 days previously had been treated with taurine in the doses as in taurine group.

During the experimental period the tail systolic blood pressure was determined by tail-cuff plethysmograph in unanesthetizad rats model LE5001-pressure meter, Letica, SA, Spain.

Blood samples were drawn, after overnight fasting (using a special micropipettes introduced through the inner contuse of rats orbit into the cavernous sinus and the head of the rat was tilted down) in clean, and sterile serum tubes. Blood samples were centrifuged for 10 minutes, at 3000 r.p.m. within an hour of the blood collection and the sera were obtained. Each serum was divided into small fractions, which were kept in deep freezer under $-20^{\circ} \mathrm{C}$ for analysis of the following different parameters, lipid profile, and taurine concentration in serum were determined, while liver function parameters have been done before freezing for all animals.

\section{RIA for T3\&T4\& Cortisone Hormones}

T3, T4 \& cortisone levels were determined by using the commercial radio immuno assay Kit (RIA) [32].

\section{Histopathological Studies}

After scarification and dissection, kidney, liver, and heart were removed immediately and fixed in $10 \%$ normal saline and neutral buffered formalin for 7 days, then the tissues were washed and dehydrated in ascending grades of ethyl alcohol cleared in benzene and impregnated in paraffin for 1.5 hour in the oven at $55^{\circ} \mathrm{C}$. Serial section, $5 \mu \mathrm{m}$ were cut and stained with Hematoxylin \& Eosin (H\&E) as described by [33].

\section{Pathology Score}

According to pathology of [34] the histopathological changes in the tissues of kidney, liver and heart were grouped in three classes: minimal, moderate and severe changes.

Score I refers to minimal changes, score II to moderate changes, while score III to severe changes.

Score I characterized by changes only in the intercellular space and blood vessels, but in score II the pathological changes affect the cell membrane up to vacuolization in cytoplasmic, while nuclear degenerative changes occur only in score III.

\section{Morphometric Study}

Thirty cases were subjected to morphometric study by CAS-200 image cytometry using the micrometer program plus software package (Version 1.0). This was carried out on the H\&E stained tissue sections at an objective magnification of $40 \mathrm{x}$ for each case. At least one hundred nuclei were selected from the most typical histological fields. The nuclear areas were measured using the (point to point) and (point and click area) modes.

Mean nuclear area and SD for each case, and the variances of the measurements were calculated. The guidelines followed were that of $[35,36]$.

\section{Statistical Analysis}

After confirmation of normal distribution for all variables, the significance of differences was evaluated by paired $t$-test or analysis of variance (ANOVA). Relationships between variables were analyzed by simple correlation analysis. Data are expressed as mean $\pm \mathrm{SD}$, and a value of $\mathrm{P}<0.05$ was the criterion for statistical significance. All statistical analyses were performed using state view-j software on a computer.

\section{RESULTS}

The present investigation was carried out to examine the possible therapeutic and protective effects of taurine as an antioxidant, in ameliorating the common side effect of toxemia during pregnancy.

Blood pressure in Table $\mathbf{1}$ showed highly significant elevation in toxemic group as compared to control group, 
Table 1. Therapeutic and Protective Effects of Taurine on Blood Pressure of Pregnancy Rats Injected with ADR

\begin{tabular}{|c|c|c|c|c|c|}
\hline & Control $(\mathbf{n}=\mathbf{1 0})$ & $\mathbf{T}(\mathbf{n}=\mathbf{1 0})$ & ADR $(\mathbf{n}=\mathbf{1 0})$ & ADR-T $(\mathbf{n}=\mathbf{1 0})$ & T-ADR $(\mathbf{n}=\mathbf{1 0})$ \\
\hline \hline Blood pressure & $107.71 \pm 0.51$ & $106 \pm 0.96 \mathrm{a}^{* * *}$ & $142.76 \pm 2.65 \mathrm{a} \mathrm{a}^{* *} \mathrm{~b}^{*}$ & $120 \pm 1.17 \mathrm{a}^{*} \mathrm{~b}^{*} \mathrm{c}^{*}$ & $110.8 \pm 0.94 \mathrm{a}^{* * *} \mathrm{~b}^{* * *} \mathrm{c}^{* * *} \mathrm{~d}^{* * *}$ \\
\hline
\end{tabular}

while in therapeutic and protective groups the blood pressure were markedly decreased than that recorded in toxemic group.

Kidney functions in Table 2 showed highly significant elevation in blood urea and creatinine in all Adriamycin treated groups (Toxemic, Therapeutic and Protective groups) as compared to control group. However, both blood urea and creatinine showed marked enhancement in Protective group than in Therapeutic group as compared to that observed in Toxemic group.
However, in protective group despite of the increase in the same parameters, these elevations were markedly less than those recorded in Toxemic group. However, lesser effects of taurine were observed in therapeutic to group where the latter enzymes showed a moderate decrease in their levels compared to Toxemic group.

Plate II shows the normal (Fig. 1), taurine (Fig. 2), and adriamycin (Fig. 3a, b) effects on liver tissue. Cellular and nuclear pleomorphism and apparent vacuolation in the cytoplasm of the hepatocytes were recorded in toxemic

Table 2. Therapeutic and Protective Effects of Taurine in Pregnant Rats Kidney Injected with Adriamycin

\begin{tabular}{|c|c|c|c|c|c|}
\hline & $\begin{array}{l}\text { Control Group } \\
(n=10)\end{array}$ & $\begin{array}{l}\text { Taurine Group } \\
\qquad(n=10)\end{array}$ & $\begin{array}{l}\text { Toxemic Group } \\
\qquad(n=10)\end{array}$ & $\begin{array}{l}\text { Therapeutic Group } \\
(\mathbf{n}=10)\end{array}$ & $\begin{array}{l}\text { Protective Group } \\
\qquad(\mathrm{n}=\mathbf{1 0})\end{array}$ \\
\hline Urea(mg/dl) & $21.10 \pm 4.18$ & $23.70 \pm 3.62 \mathrm{a}^{*}$ & $69.90 \pm 6.57 \mathrm{a}^{*}$ & $56.90 \pm 4.63 \mathrm{a}^{* * *}, \mathrm{~b} * * *, \mathrm{c} * *$ & $49.81 \pm 5.58 \mathrm{a}^{* * *}, \mathrm{~b} * * *, \mathrm{c}^{* *}, \mathrm{~d}^{*}$ \\
\hline Creatinine(mg/dl) & $0.54 \pm 0.16$ & $0.16 \pm 0.16$ & $1.18 \pm 0.18 \mathrm{a}^{* * *}$ & $1.11 \pm 0.23 \mathrm{a}^{* * *}, \mathrm{~b} * * *$ & $0.98 \pm 0.23 \mathrm{a}^{* * *}, \mathrm{~b} * *, \mathrm{c} *$ \\
\hline \multicolumn{6}{|c|}{$\begin{array}{l}\text { Non significant }<0.05 \\
* \text { Significant }<0.05 \\
* * \text { highly Significant }<0.01 \\
* * * \text { very highly Significant }<0.05\end{array}$} \\
\hline
\end{tabular}

The nephropathy scores of different adriamycin treated groups were shown in Table 3. In toxemic group, 10 rats showed lesions with score of III in 2 rats score II in 3 rats and score I in 5 rats. However, these nephritic lesions were alleviated in the groups where taurine either protectively or therapeutically was given in Table $\mathbf{3}$.

Plate I (Fig. 3a, b) showed the normal (Fig. 1) and histopathological changes in rat's kidney tissue after treatment with taurine alone (Fig. 2) and adriamycin alone (Fig. 3a, b), which showed necrosis of the epithelial lining of tubules and obliteration of the glomerular capillaries and adhesions of the glomerular epithelium with massive vacuolization in the cytoplasm. However, Plate IV illustrates the effects on kidney tissue when taurine was used either therapeutically (Fig. $\mathbf{4 a}, \mathbf{4 b}$ ) or protectively (Fig. 5a, b).

Table 4 clearly showed that all liver enzymes (AST, ALT, ALP) and bilirubin were not significantly changed in therapeutic group as compared to control. While in Toxemic group, the latter enzymes and bilirubin were markedly elevated. group. The hepatocytes in numerous hepatic lobules showed variation in nuclear size: some have small nuclei whereas in other the cells were large with longer nuclei. The blood vessels are congested with an increase in Kupffer cells. At the peripheral zones of the hepatic lobules, the hepatocytes were markedly vacuolated.

However, Plate V shows the histopathological changes in rat's liver tissue when taurine was administrated therapeutically (Fig. 4a, b) and protectively (Fig. 5a, b) in adriamycin treated groups. Mild improvement was observed in Therapeutic group compared to marked improvement in the hepatic architecture that was noticed in protective group. The latter observations were clearly illustrated in the histopathological score of liver in different treated groups in Table 5. Seven out of ten rats who were given adriamycin had severe lesion in score III, 2 rats in score II and one rat in score I. Whereas in therapeutic group 6 rats had lesion with score III and 3 had lesion in score II. But in the Protective group, only 3 rats had lesion with score III and 5 rats in score II.

Table 3. Nephropathy Score in Different Adriamycin Treated Groups

\begin{tabular}{|c|c|c|c|c|}
\hline Groups & $\begin{array}{c}\text { Score 0 } \\
\text { Number of No Changes }\end{array}$ & $\begin{array}{c}\text { Score I } \\
\text { Number of Minimal Changes }\end{array}$ & $\begin{array}{c}\text { Score II } \\
\text { Number of Moderate Changes }\end{array}$ & $\begin{array}{c}\text { Score III } \\
\text { Number of Severe Changes }\end{array}$ \\
\hline \hline Toxemic Group (n=10) & 0 & 5 & 3 & 2 \\
\hline Therapeutic group (n=10) & 0 & 5 & 4 & 1 \\
\hline Protective group $(\mathbf{n}=\mathbf{1 0})$ & 0 & 7 & 2 & 1 \\
\hline
\end{tabular}



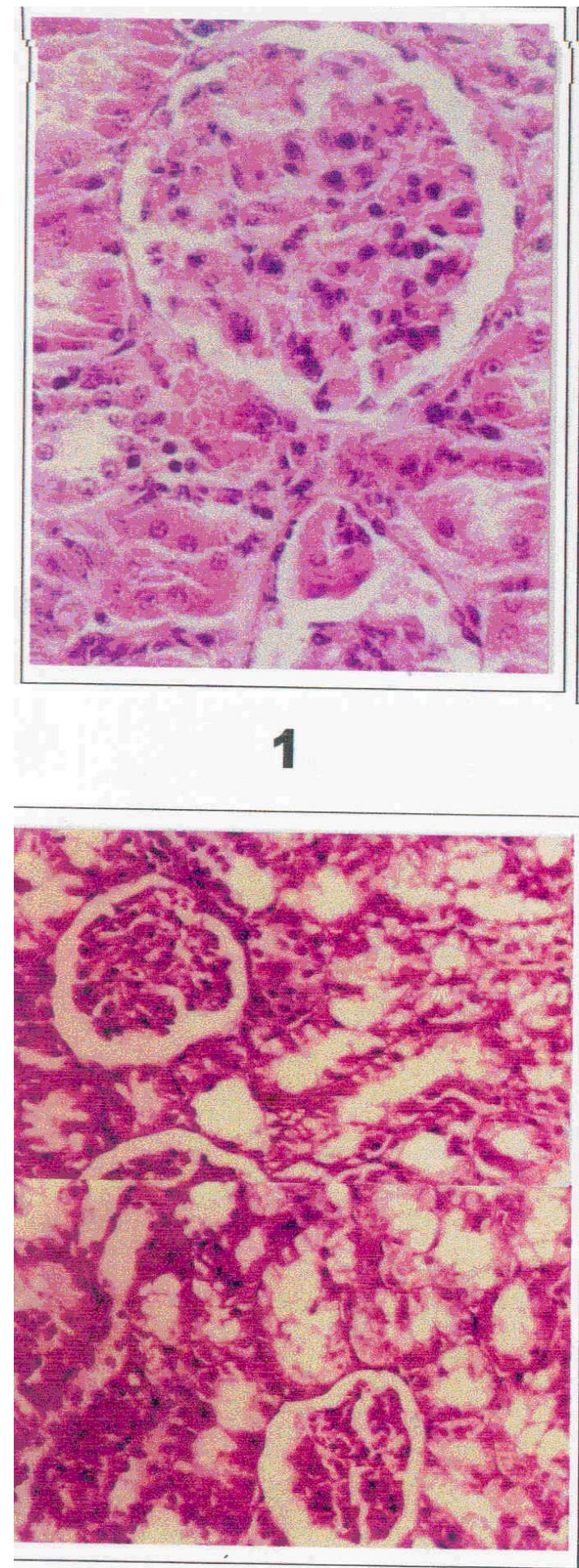

3-a

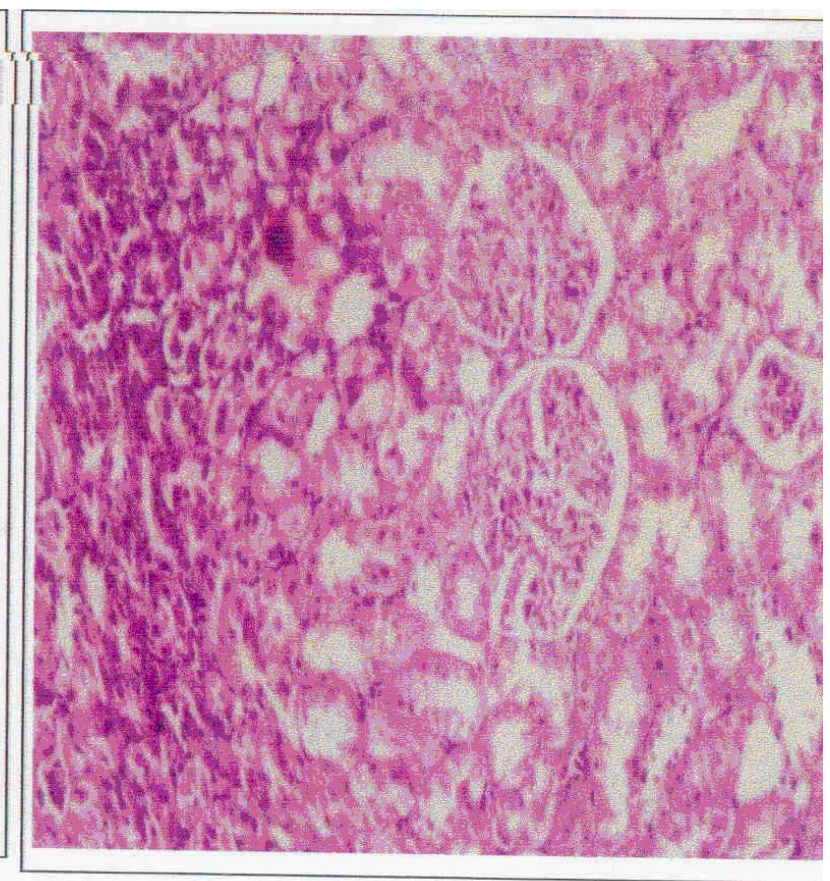

2

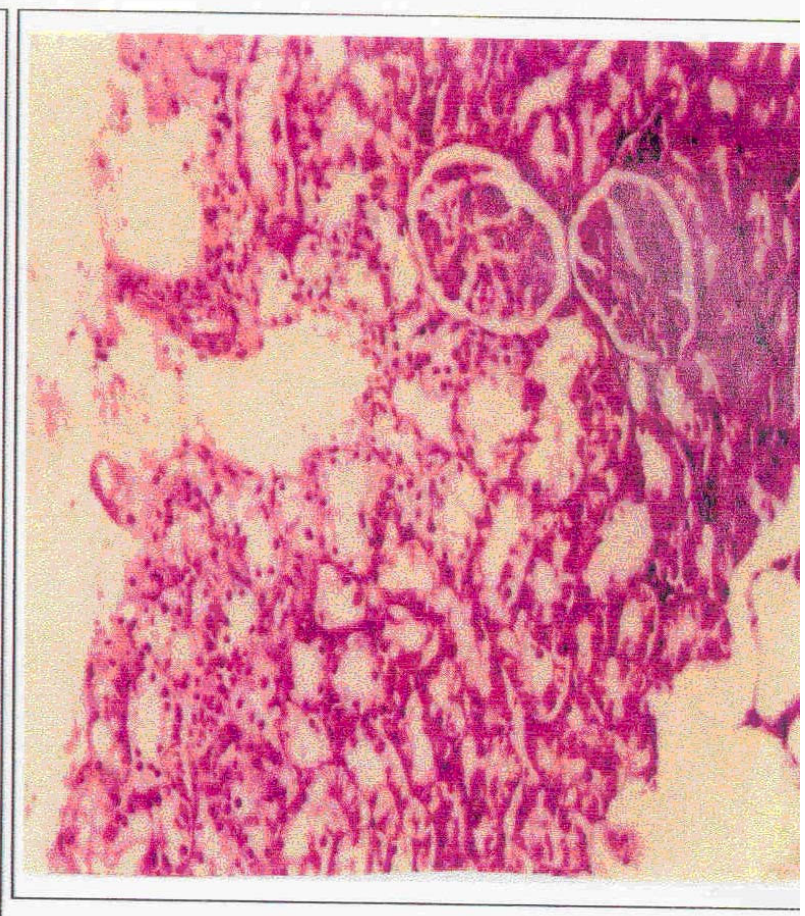

3-b

\section{Plate I}

Plate (I). Histopathological changes in rat's kidney tissue treated with Adriamycin and Taurine.

Fig. (1). Normal kidney showed a patent glomeruli and intact tubules (H \& E, x 225).

Fig. (2). Kidney of rat after taurine administration showed normal appearance of glomeruli and tubules (H \& E, x 225).

Fig. (3). Kidney of rat after ADR administration showed necrosis of the epithelial lining of the tubules and obliteration of the glomerular capillaries and adhesions of the glomerular epithelium with massive vacuolization in the cytoplasm (H \& E, x 225). 
Table 4. Therapeutic and Protective Effects of Taurine in Pregnant Rats Liver Injected with Adriamycin

\begin{tabular}{|c|c|c|c|c|c|}
\hline & $\begin{array}{c}\text { Control Group } \\
(\mathbf{n}=\mathbf{1 0})\end{array}$ & $\begin{array}{c}\text { Taurine Group } \\
(\mathbf{n = 1 0})\end{array}$ & $\begin{array}{c}\text { Toxemic Group } \\
(\mathbf{n = 1 0 )}\end{array}$ & $\begin{array}{c}\text { Therapeutic Group } \\
(\mathbf{n = 1 0})\end{array}$ & $\begin{array}{c}\text { Protective Group } \\
(\mathbf{n}=\mathbf{1 0})\end{array}$ \\
\hline \hline AST(u/l) & $127.95 \pm 15.47$ & $112.50 \pm 10.61$ & $201.60 \pm 19.05 \mathrm{a}^{* * *}$ & $177.20 \pm 15.55 \mathrm{a}^{* * *}, \mathrm{~b}^{* * *}, \mathrm{c}^{* *}$ & $163.30 \pm 18.03 \mathrm{a}^{* * *}, \mathrm{~b}^{* * *}, \mathrm{c}^{* * *}$ \\
\hline ALT(u/l) & $37.30 \pm 6.74$ & $32.45 \pm 7.72$ & $69.68 \pm 7.67 \mathrm{a}^{* * *}$ & $60.05 \pm 7.19 \mathrm{a}^{* * *}, \mathrm{~b}^{* * *}, \mathrm{c}^{*}$ & $55.65 \pm 8.23 \mathrm{a}^{* * *}, \mathrm{~b}^{* * *}, \mathrm{c}^{* *}, \mathrm{~d}^{*}$ \\
\hline ALP(u/l) & $27.90 \pm 4.68$ & $27.65 \pm 4.18$ & $70.25 \pm 5.99 \mathrm{a}^{* * *}$ & $60.65 \pm 6.81 \mathrm{a}^{* * *}, \mathrm{~b}^{* * *}, \mathrm{c}^{* * *}$ & $52.05 \pm 4.59 \mathrm{a}^{* * *}, \mathrm{~b}^{* * *}, \mathrm{c}^{* * *}, \mathrm{~d}^{*}$ \\
\hline Bilirubin(mg/dl) & $0.67 \pm 0.14$ & $0.66 \pm 0.10$ & $1.06 \pm 0.18 \mathrm{a}^{* * *}$ & $1.04 \pm 0.21 \mathrm{a}^{* *}, \mathrm{~b}^{* * *}$ & $1.01 \pm 0.22 \mathrm{a}^{* *}, \mathrm{~b}^{* *}$ \\
\hline
\end{tabular}

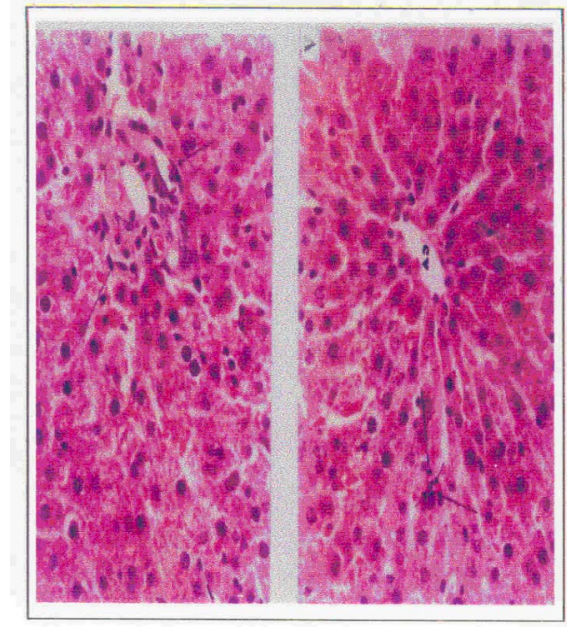

1

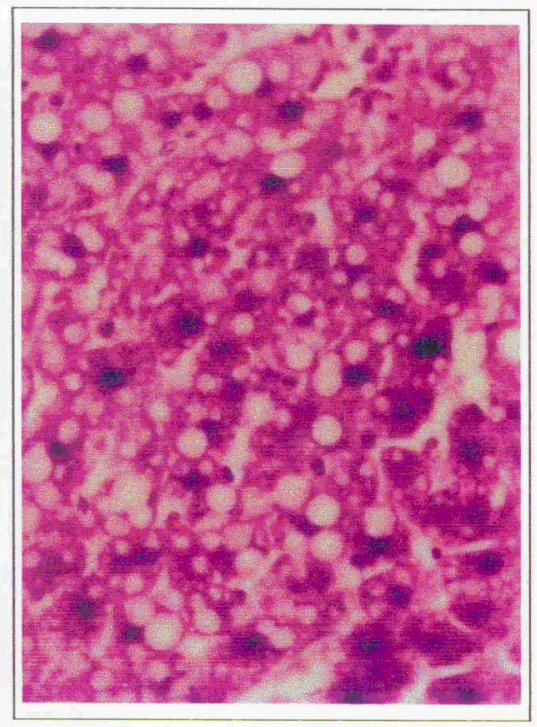

3-a

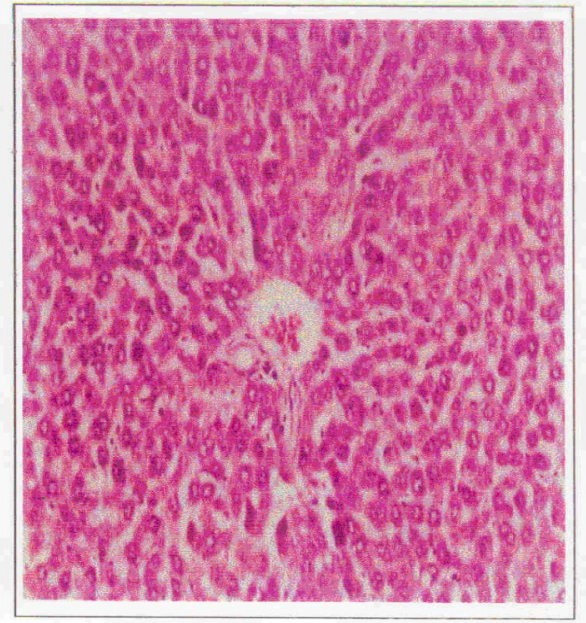

2

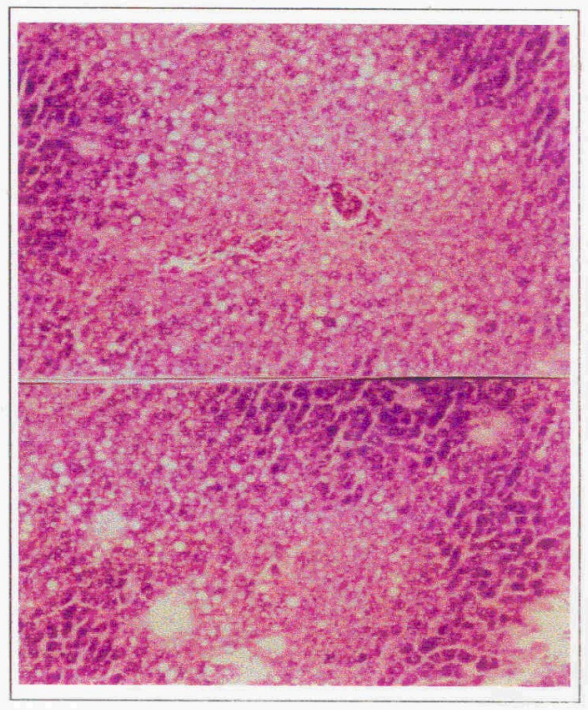

3-b

Plate II

Plate II. Histopathological changes in rat's liver tissue treated with Adriamycin and Taurine.

Fig. (1). Normal liver of the rat (control) showed the normal architecture of hepatocytes (H \& E, x 225).

Fig. (2). Liver of rat after taurine administration showed normal architecture of hepatocytes (H \&E, x 225).

Fig. (3a). Liver of rat after ADR administration showed the cytoplamic vacuolization and fat degeneration of hepatocytes involving most of hepatic lobule and dilatation in the sinusoidal spaces with congested blood vessels (H \& E, x 225).

Fig. (3b). Liver rat after ADR administration showed the extensive diffuse fat degeneration and hyperplasia in Kupffer cells (H \& E, x 225). 
Table 5. Hepatological Score in Different Adriamycin Treated Rats

\begin{tabular}{|c|c|c|c|c|}
\hline Groups & $\begin{array}{c}\text { Score 0 } \\
\text { Number of No Changes }\end{array}$ & $\begin{array}{c}\text { Score I } \\
\text { Number Of Minimal Changes }\end{array}$ & $\begin{array}{c}\text { Score II } \\
\text { Number of Moderate Changes }\end{array}$ & $\begin{array}{c}\text { Score III } \\
\text { Number of Sever Changes }\end{array}$ \\
\hline \hline Toxemic group (n=10) & 0 & 1 & 2 & 7 \\
\hline Therapeutic group (n=10) & 0 & 1 & 3 & 6 \\
\hline Protective group $(\mathbf{n}=\mathbf{1 0})$ & 0 & 2 & 5 & 3 \\
\hline
\end{tabular}

Table 6. Therapeutic and Protective Effects of Taurine on Lipidogram of Pregnant Rats Injected with Adriamycin

\begin{tabular}{|c|c|c|c|c|c|}
\hline & $\begin{array}{c}\text { Control Group } \\
(n=10)\end{array}$ & $\begin{array}{c}\text { Taurine Group } \\
(\mathbf{n}=10)\end{array}$ & $\begin{array}{l}\text { Toxemic Group } \\
\qquad(\mathrm{n}=10)\end{array}$ & $\begin{array}{l}\text { Therapeutic Group } \\
\qquad(\mathrm{n}=10)\end{array}$ & $\begin{array}{c}\text { Protective Group } \\
(n=10)\end{array}$ \\
\hline T.Ch. (mg/dl) & $55.25 \pm 4.28$ & $42.25 \pm 7.33 \mathrm{a}^{* * *}$ & $98.95 \pm 10.98 \mathrm{a}^{* * *}$ & $90.65 \pm 6.23 \mathrm{a}^{* * *}, \mathrm{~b}^{* * *}$ & $79.15 \pm 6.62 \mathrm{a}^{* * *}, \mathrm{~b}^{* * *}, \mathrm{c}^{* * *}, \mathrm{~d}^{* *}$ \\
\hline TG. (mg/dl) & $44.90 \pm 7.50$ & $43.15 \pm 8.4$ & $90.05 \pm 8.28 \mathrm{a}^{* * *}$ & $79.05 \pm 7.09 \mathrm{a}^{* * *}, \mathrm{~b}^{* * *}, \mathrm{c} * *$ & $72.45 \pm 8.30 \mathrm{a}^{* * *}, \mathrm{~b}^{* * *}, \mathrm{c}^{* * *}$ \\
\hline HDL (mg/dl) & $13.20 \pm 2.36$ & $11.50 \pm 1.72$ & $19.70 \pm 2.57 \mathrm{a}^{* *}$ & $17.70 \pm 2.39 \mathrm{a}^{* *}, \mathrm{~b}^{* * *}$ & $18.00 \pm 2.7 \mathrm{a}^{* * *}, \mathrm{~b}^{* * *}, \mathrm{c}^{* * *}, \mathrm{~d}^{* *}$ \\
\hline LDL (mg/dl) & $32.95 \pm 4.52$ & $21.33 \pm 3.31 \mathrm{a}^{* * *}$ & $63.69 \pm 6.72 \mathrm{a}^{* * *}$ & $56.96 \pm 5.94 \mathrm{a}^{* * *}, \mathrm{~b}^{* * *}$ & $45.24 \pm 4.04 \mathrm{a}^{* * *}, \mathrm{~b}^{* * *}, \mathrm{c}^{* * *}, \mathrm{~d}^{* *}$ \\
\hline VLDL (mg/dl) & $6.63 \pm 1.40$ & $6.05 \pm 1.23$ & $12.53 \pm 1.695 \mathrm{a}^{* * *}$ & $11.37 \pm 1.68 \mathrm{a}^{* * *}, \mathrm{~b}^{* * *}$ & $8.99 \pm 1.51 \mathrm{a}^{* * *}, \mathrm{~b}^{* * *}, \mathrm{c}^{* * *}, \mathrm{~d}^{* *}$ \\
\hline
\end{tabular}

Regarding to lipid parameters, in Table 6 showed marked elevation in all of them in toxemic group. These elevations were significantly decreased in rats therapeutically treated with taurine. Attractively, lipid parameter in protective group showed a difference markedly lower than that recorded in toxemic or therapeutic groups (Table 6).

The main cardiac pathological changes identified with ADR administration were myofibrillar loss and cytoplasmic vacuolization Plate III (Fig. 3a, b) examined by light microscope. However, Plate VI (Fig. 4a, b, c) showed moderate degrees of necrosis of the cardiac muscle of rat after adriamycin administration in therapeutic group. Fig. $(\mathbf{5 a}, \mathbf{b})$ showed minimal edema and congestion with absence of necrosis, showing minimal lessened vacuolization in protective group.

The cardiomyopathy scores from all animals in each group are showed in Table 7. There was no significant difference between the severities of the lesion scores in the three groups. The most severe lesion score was found in Toxemic groups or in Therapeutic group. The least severe monocyte alternations were found in rats of the protective group.

The most important point in this work was mentioned in Table 8 which showed that serum taurine levels was markedly decreased in toxemic group, referring to that recorded in control group. Moreover, the therapeutic use of taurine did not significantly change the serum taurine level in rats. While the protective use of taurine showed a significant elevation in its serum level compared to that recorded in toxemic group.

Regarding to morphometric studies, the measurement of nuclear area in liver, kidney and heart cells in all groups were shown in Table 9.

Table 10 showed a significant increase in T3 and T4 in Toxemic group, Therapeutic groups and Protective groups referring to that observed in control group. Also there was a marked decrease in the level of cortisone in both therapeutic and protective groups.

\section{DISCUSSION}

In the present study, the possible use of the antioxidant taurine in ameliorating the adverse effects of toxemia during pregnancy was investigated. The female rat was used as an animal model for induction of hypertension by adriamycin injection. The injection with adriamycin led to a marked elevation in the tail systolic blood pressure (TSBP) due to the elevation of free radicals production, cardiotoxicity and nephrotoxicity of adriamycin. These elevations are due to angiotensin II and it can directly stimulate the epithelial sodium channels in the distal tubules and results in increased sodium reabsorption [2, 21, 37].

The kidney function, urea and creatinine measurements, showed marked improvements when taurine was administrated to ADR induced toxemia in rats. However, the improvement was better in the Protective group than in the Therapeutic group. These improvements were also confirmed by the nephropathy score into different ADR treated groups, which illustrated mild nephrotic lesions when taurine administrated protectively.

The histopathological architecture of the kidney in all adriamycin treated groups showed different degrees of necrosis and glomerular congestion; however, in protective group these abnormalities were markedly improved. Most of the described renal pathology of adriamycin was reported on light microscopy. However, renal pathology may be concluded indirectly by measuring the biochemical changes in renal functions rather than morphologic changes. The highly significant elevation in the levels of both blood urea and serum creatinine and the decrease in the morphometry of the renal cells in the same group were found. 

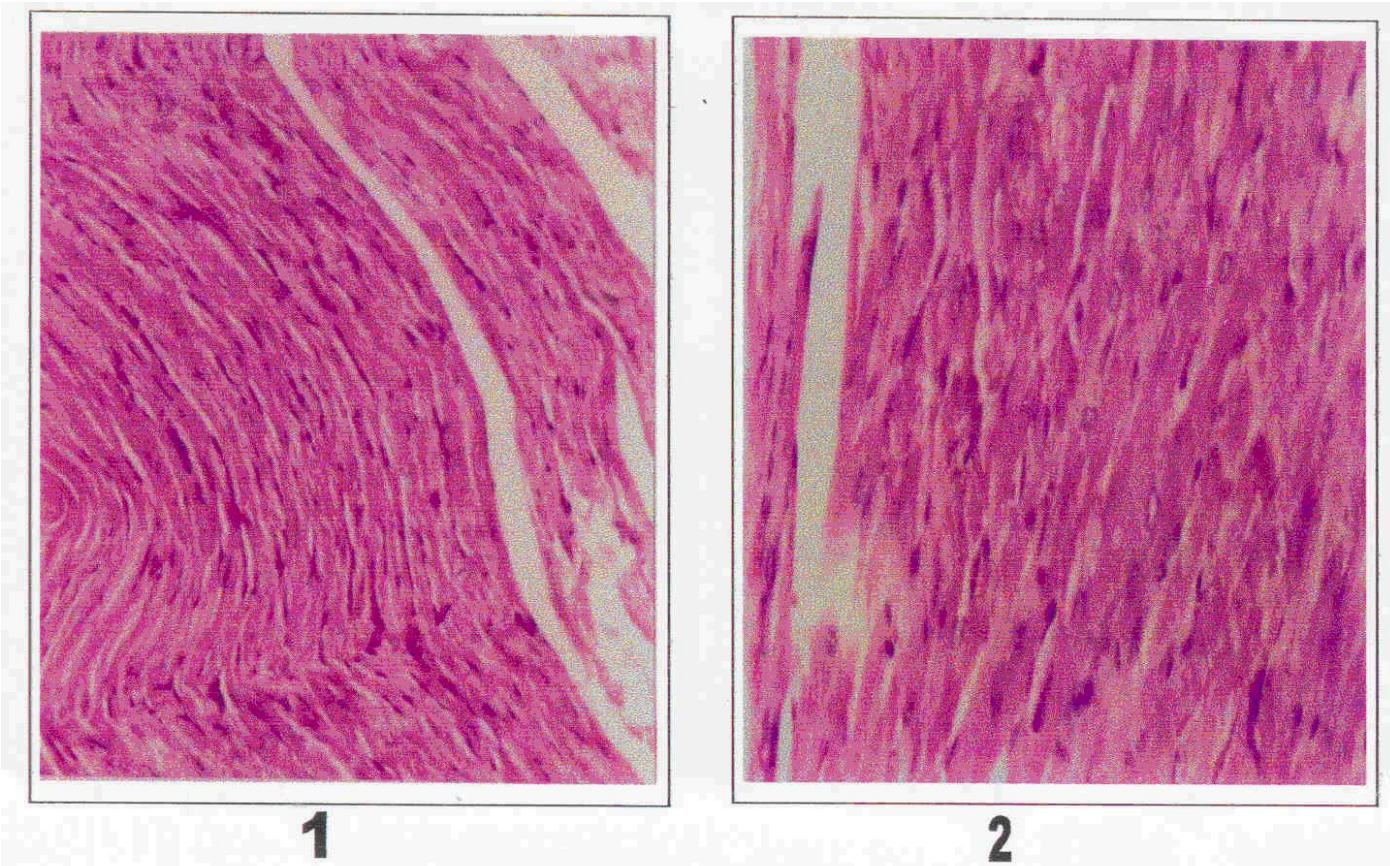

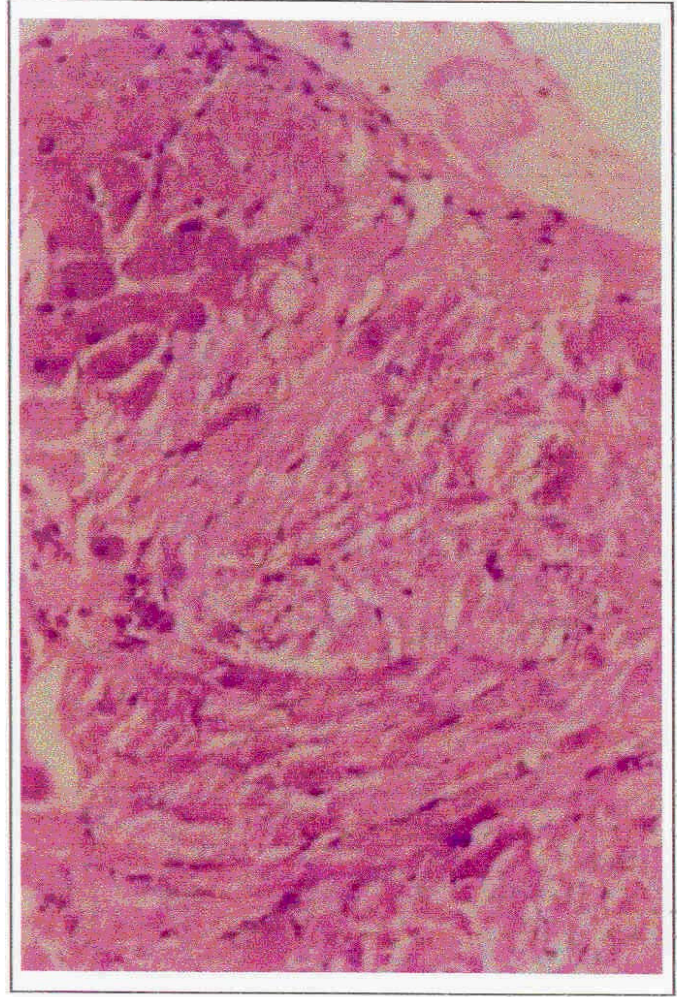

3-a

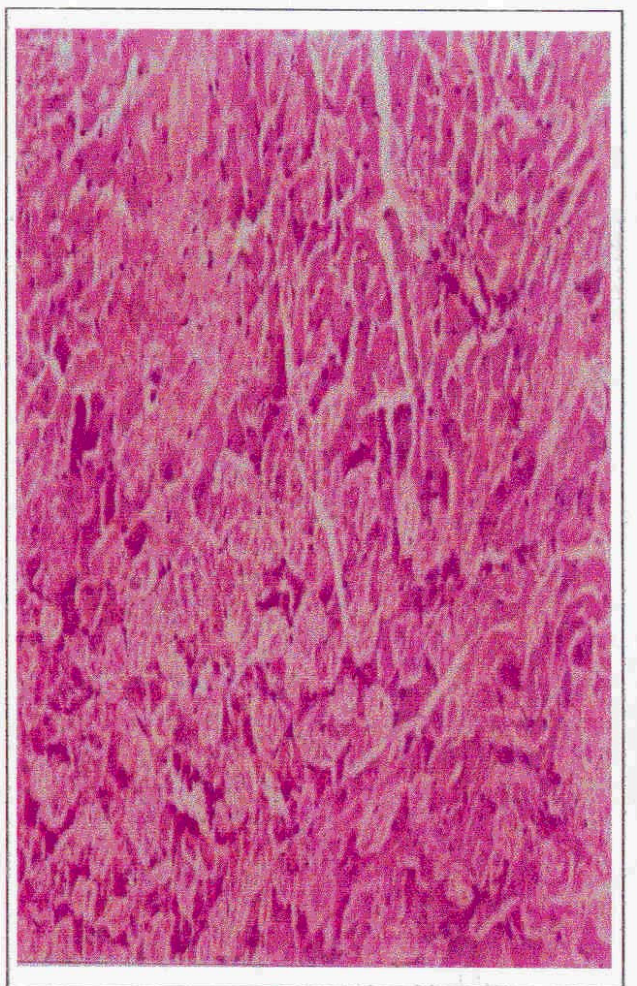

$3=b$

\section{Plate III}

\section{Plate III. Histopathological changes in rat's heart tissue treated with Adriamycin and Taurine.}

Fig. (1). Normal heart of the rat (control) showed absence of myofibrillar necrosis or vacuolization (H \& E, x 225).

Fig. (2). Heart of rat after taurine administration showed the normal architecture of cardiac muscle. (H \&E, x 225).

Fig. (3a). Heart of rat after ADR administration showed the extensive edema with vacuolization and severe necrosis (H \& E, x 225).

Fig. (3b). Heart of rat after ADR administration showed the extensive edema with myofibrillar necrosis (H \& E, x 225). 
Table 7. Cardiomyopathy Score in Different Adriamycin Treated Rats

\begin{tabular}{|c|c|c|c|c|}
\hline Groups & $\begin{array}{c}\text { Score 0 } \\
\text { Number of No Changes }\end{array}$ & $\begin{array}{c}\text { Score I } \\
\text { Number of Minimal Changes }\end{array}$ & $\begin{array}{c}\text { Score II } \\
\text { Number of Moderate Changes }\end{array}$ & $\begin{array}{c}\text { Score III } \\
\text { Number of Sever Changes }\end{array}$ \\
\hline \hline Toxemic group (n=10) & 0 & 0 & 4 & 6 \\
\hline Therapeutic group (n=10) & 0 & 3 & 2 & 5 \\
\hline Protective group $(\mathbf{n = 1 0})$ & 3 & 2 & 2 & 5 \\
\hline
\end{tabular}

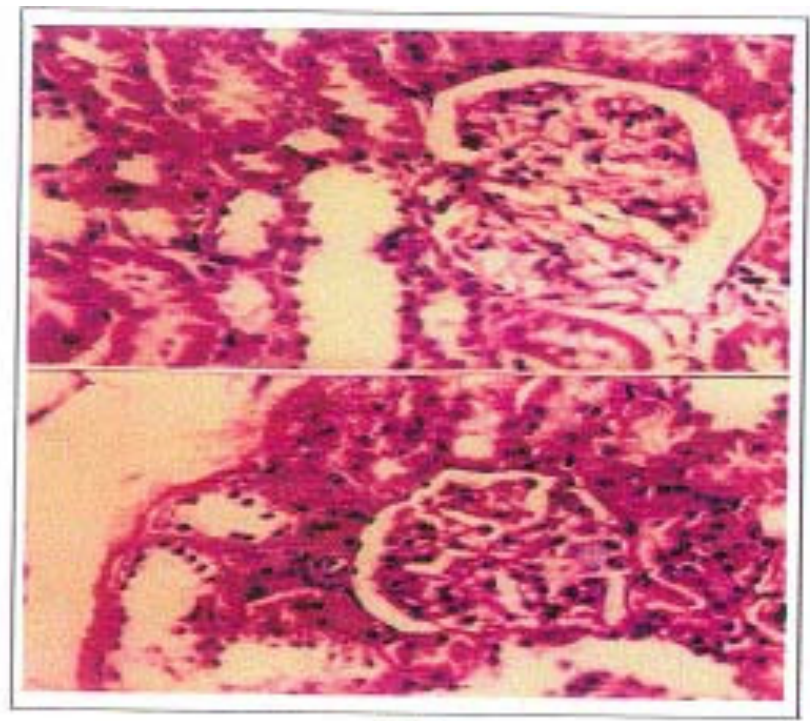

4-a

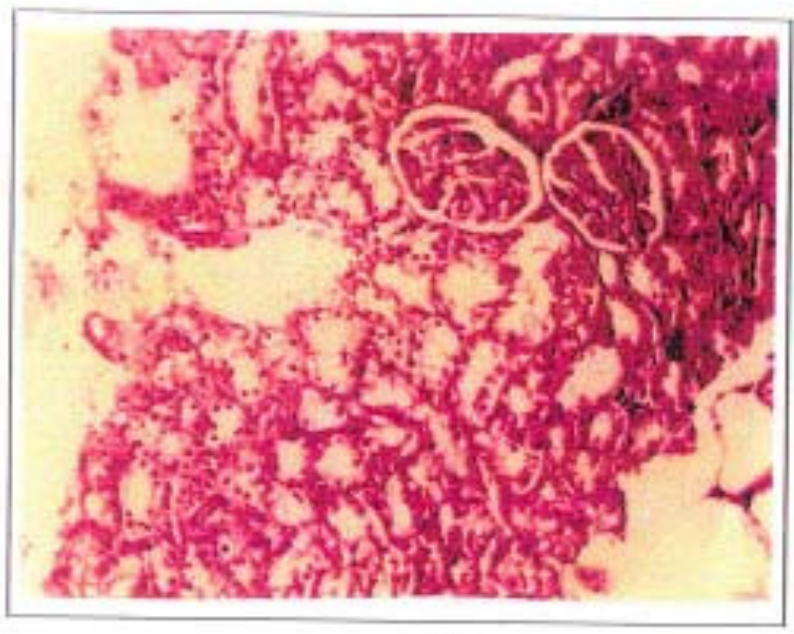

5-a

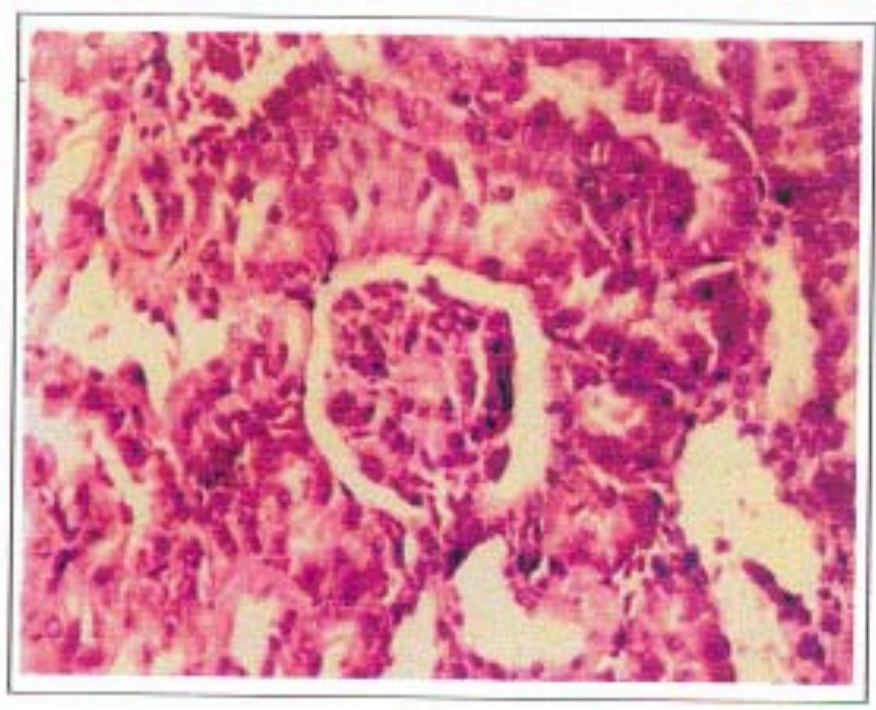

4-b

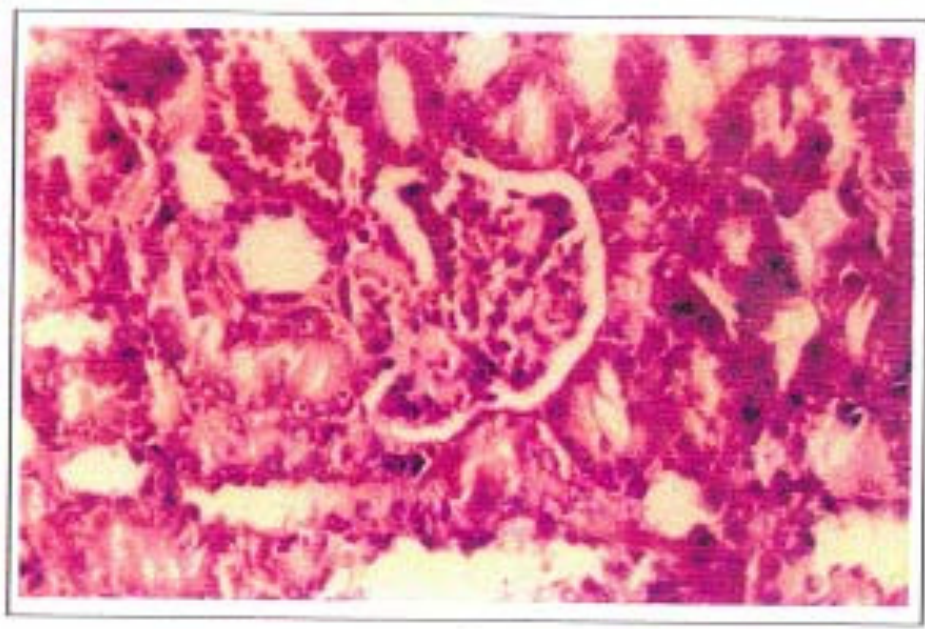

5-b

\section{Plate IV}

Plate IV. Histopathological changes in rat's kidney tissue treated with Adriamycin and Taurine.

Fig. (4a, b). Kidney of the rat in therapeutic group showed the necrosis of tubules and congestion of the glomeruli (H \& E, x 225).

Fig. (5a, b). Kidney of rat in protective group showed a partial degeneration in the tubules and mild glomerular congestion. (H \&E, $\mathrm{x} 225$ ). 


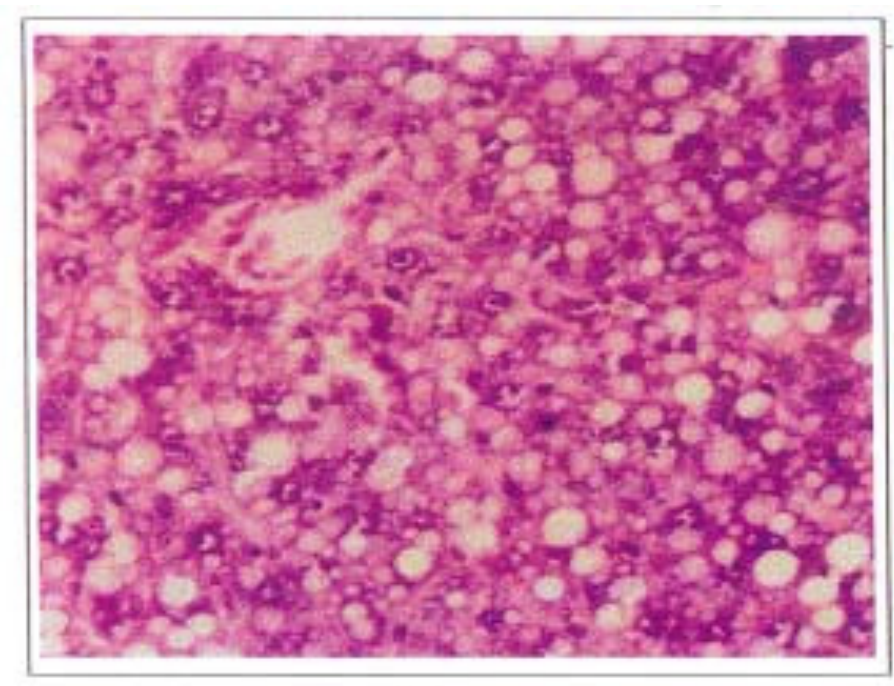

4-a

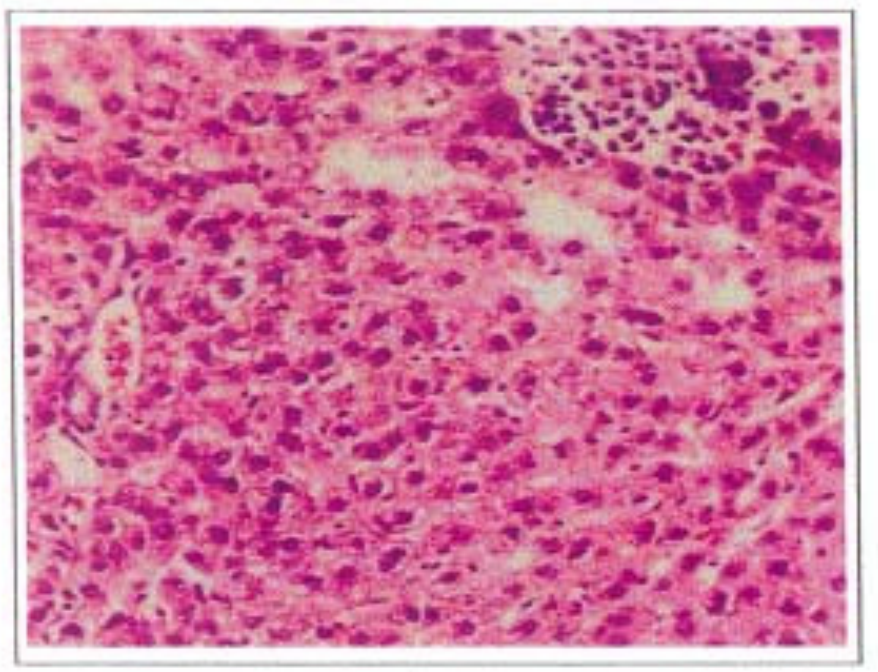

5-a

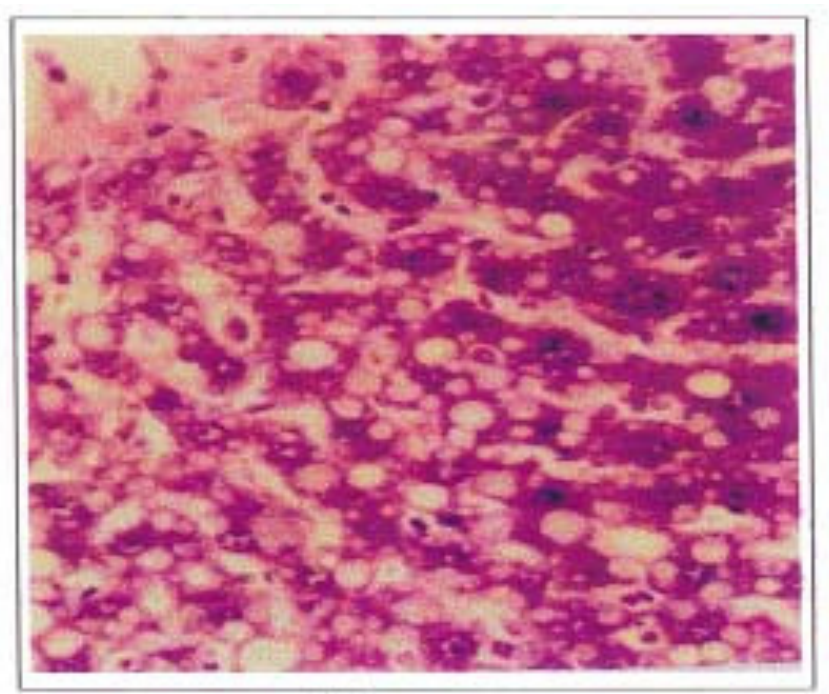

4-b

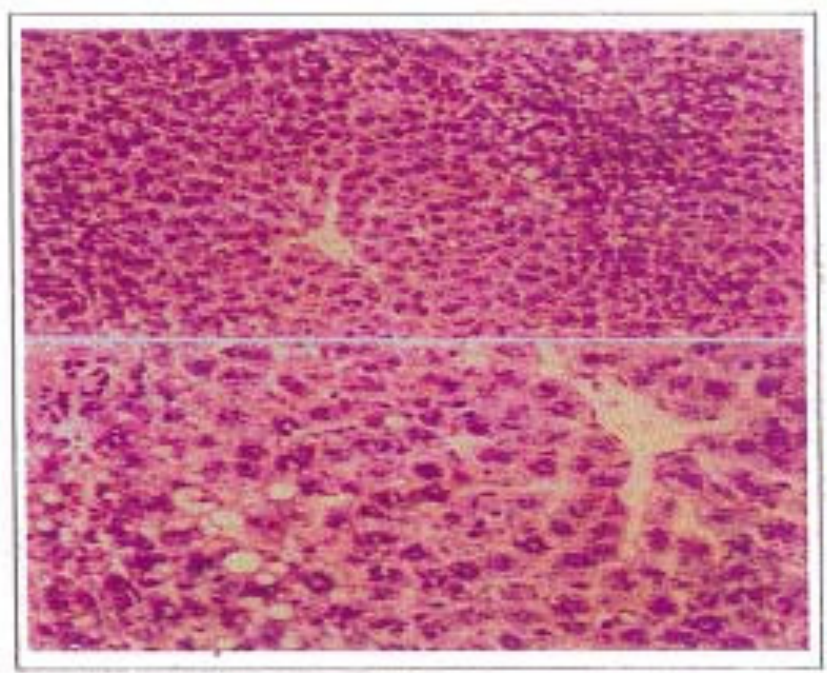

5-b

\begin{abstract}
The latter observations may be attributed to a progressive generation of free radicals, which attack the kidney tissue and led to a disturbance in the lipid peroxidation levels. Therefore, the free radicals accelerate the cell damage and precipitate chronic glomerulonephritis [38-40]. While, the injection of rats with adriamycin leads to the elevation in the level of phospholipidosis enzymes in the lysosomes, these enzymes inhibit $\mathrm{Na}^{+}-\mathrm{K}^{+}$-ATPase which leads to increase in the free radical formation $[41,42]$.
\end{abstract}

Plate

Plate V: Histopathological changes in rat's liver tissue treated with Adriamycin and Taurine.

Fig. (4a, b). Liver of rat in therapeutic group showed the extensive diffuse fatty degeneration (H \& E, x 225).

Fig. (5a). Liver of rat in protective group showed the mild congestion and absence of necrosis. (H \&E, x 225).

Fig. (5b). Liver of rat in protective group showed a limited fatty change and vacuolization of the hepatocytes. (H \& E, x 225).

The biochemical disturbances in the kidney functions were also suggested to be due to the ability of ADR to reduce phagocytic activity of the reticuloendothelial system [43]. Moreover, the nephrotoxicity of ADR to its ability to be accumulated in the renal cells through peritubular capillaries and pinocytotic reabsorption of drug from the glomerular filtrate, which were rapidly incorporated in lysosomes. Accordingly, lysosomal swelling followed by their rupture could have induced the degeneration of tubular cells $[44,45]$. 

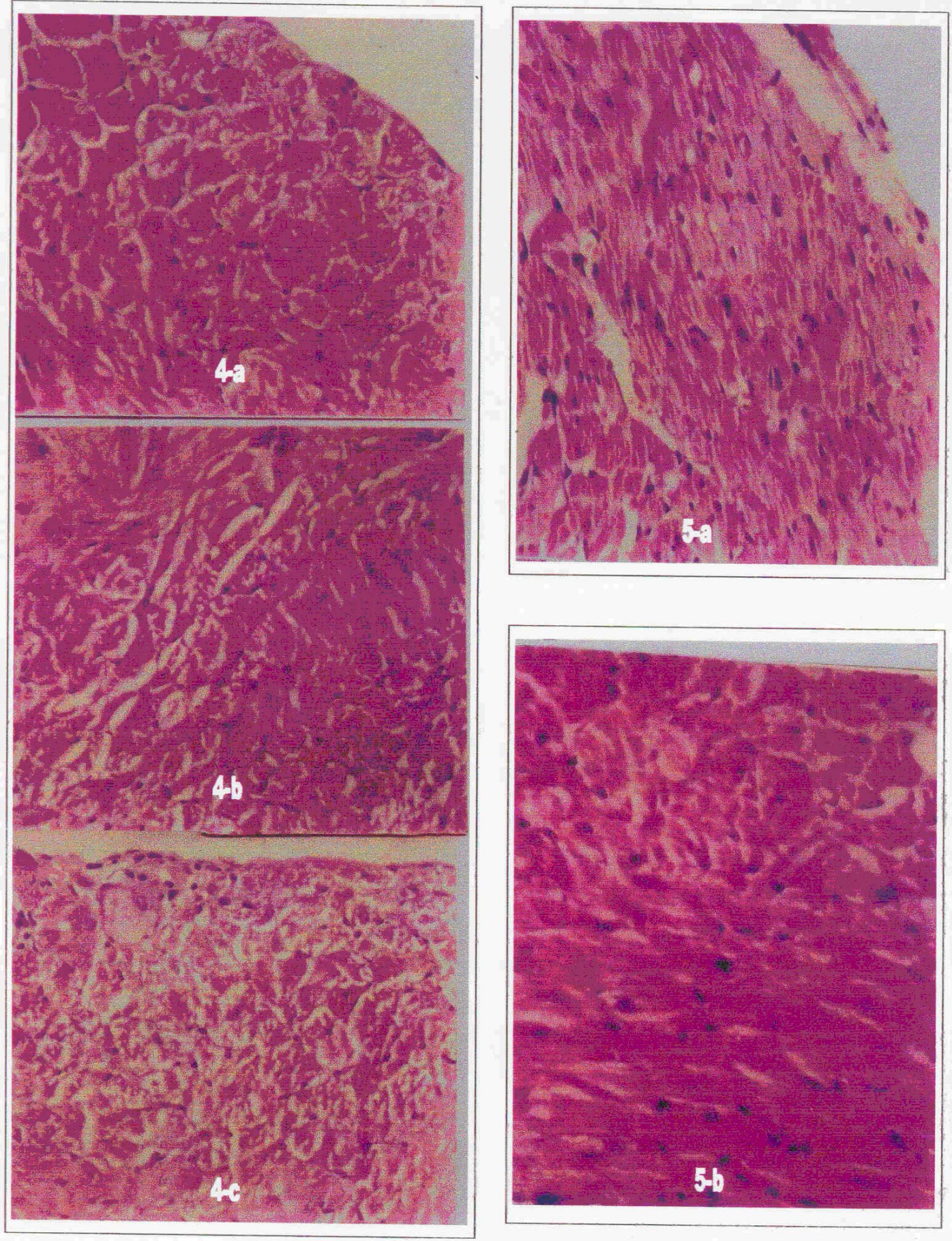

\section{Plate VI}

\section{Plate VI. Histopathological changes in rat's heart tissue treated with Adriamycin and Taurine.}

Fig. (4a). Cardiac muscle of rat in therapeutic group the score "1" necrosis. (H \& E, x 225).

Fig. (4b). Cardiac muscle of rat in therapeutic group the score "2" necrosis. (H \&E, x 225).

Fig. (4c). Cardiac muscle of rat in therapeutic group the score "3" necrosis. (H \& E, x 225).

Fig. (5a). Cardiac muscle of rat in protective group showed the minimal edema and congestion and absence of necrosis (H \& E, x 225).

Fig. (5b). Cardiac muscle of rat in protective group showed the minimal and lessened vacuolization (H \& E, x 225). 
Table 8. Serum Taurine Level in Pregnant Rats Injected with Adriamycin

\begin{tabular}{|c|c|c|c|c|c|}
\hline & $\begin{array}{c}\text { Control Group } \\
(\mathbf{n}=\mathbf{1 0})\end{array}$ & $\begin{array}{c}\text { Taurine Group } \\
(\mathbf{n}=\mathbf{1 0})\end{array}$ & $\begin{array}{c}\text { Toxemic Group } \\
(\mathbf{n = 1 0})\end{array}$ & $\begin{array}{c}\text { Therapeutic Group } \\
(\mathbf{n}=10)\end{array}$ & $\begin{array}{c}\text { Protective Group } \\
(\mathbf{n}=\mathbf{1 0})\end{array}$ \\
\hline \hline Taurine $(\boldsymbol{\mu \mathrm { mol } / \mathrm { l } )}$ & $50.35 \pm 5.30$ & $56.51 \pm 6.39 \mathrm{a}^{* *}$ & $40.16 \pm 4.36 \mathrm{a}^{* * *}$ & $41.50 \pm 4.25 \mathrm{a}^{* *}, \mathrm{~b}^{* * *}$ & $47.87 \pm 4.45 \mathrm{~b}^{* * *}, \mathrm{c}^{* *}, \mathrm{~d}^{* * *}$ \\
\hline
\end{tabular}

Table 9. Therapeutic and Protective Effects of Taurine on the Morphometry in Some Organs of Pregnant Rats Injected with Adriamycin

\begin{tabular}{|c|c|c|c|c|c|}
\hline & $\begin{array}{c}\text { Control Group } \\
(\mathbf{n}=\mathbf{1 0})\end{array}$ & $\begin{array}{c}\text { Taurine Group } \\
(\mathbf{n = 1 0 )}\end{array}$ & $\begin{array}{c}\text { Toxemic Group } \\
(\mathbf{n}=\mathbf{1 0})\end{array}$ & $\begin{array}{c}\text { Therapeutic Group } \\
(\mathbf{n = 1 0})\end{array}$ & $\begin{array}{c}\text { Protective Group } \\
(\mathbf{n}=\mathbf{1 0})\end{array}$ \\
\hline \hline Kidney $\left(\boldsymbol{\mu \mathbf { m } ^ { 2 } )}\right.$ & $18.35 \pm 2.64$ & $22.14 \pm 3.03 \mathrm{a}^{*}$ & $12.99 \pm 1.56 \mathrm{a}^{* *}$ & $15.62 \pm 1.74 \mathrm{~b}^{* *}, \mathrm{c}^{*}$ & $16.71 \pm 1.45 \mathrm{~b}^{* *}, \mathrm{c}^{* *}$ \\
\hline Liver $\left(\boldsymbol{\mu \mathbf { m } ^ { 2 } )}\right.$ & $51.60 \pm 4.76$ & $56.76 \pm 9.17$ & $33.84 \pm 5.12 \mathrm{a}^{* * *}$ & $44.47 \pm 7.21 \mathrm{~b}^{*}, \mathrm{c}^{*}$ & $49.79 \pm 4.08 \mathrm{c}^{* * *}$ \\
\hline Heart $\left(\boldsymbol{\mu \mathbf { m } ^ { 2 } )}\right.$ & $6.89 \pm 0.89$ & $7.78 \pm 0.76$ & $4.60 \pm 0.72 \mathrm{a}^{* *}$ & $5.71 \pm 0.70 \mathrm{a}^{*}, \mathrm{~b}^{* *}, \mathrm{c}^{*}$ & $6.05 \pm 0.87 \mathrm{~b}^{* *}, \mathrm{c}^{*}$ \\
\hline
\end{tabular}

Data are expressed as mean \pm SD

a refers to control group.

c refers to ADR group.

$\begin{array}{ll}\text { Non significant }<0.05 & \text { b refers to Taurine group } \\ * * \text { highly Significant }<0.01 & \text { d refers to ADR }- \text { T group }\end{array}$

* Significant $<0.05$

$* * *$ Very highly Significant $<0.05$

Table 10. Therapeutic and Protective Effects of Taurine on T3 and T4 of Pregnancy Rats Injected with ADR

\begin{tabular}{|c|c|c|c|c|c|}
\hline & $\begin{array}{c}\text { Control Group } \\
(\mathbf{n}=\mathbf{1 0})\end{array}$ & $\begin{array}{c}\text { Taurine Group } \\
(\mathbf{n}=\mathbf{1 0})\end{array}$ & $\begin{array}{c}\text { Toxemic Group } \\
(\mathbf{n}=\mathbf{1 0})\end{array}$ & $\begin{array}{c}\text { Therapeutic Group } \\
(\mathbf{n}=\mathbf{1 0})\end{array}$ & $\begin{array}{c}\text { Protective Group } \\
(\mathbf{n}=\mathbf{1 0})\end{array}$ \\
\hline \hline T3 & $0.67 \pm 0.0912$ & $0.64 \pm 0.147$ & $0.83 \pm 0.180 \mathrm{a}^{*} \mathrm{~b}^{* *}$ & $0.78 \pm 0.136 \mathrm{a}^{* *} \mathrm{~b}^{* *}$ & $0.71 \pm 0.09 \mathrm{c}^{*}$ \\
\hline T4 & $40.12 \pm 5.8$ & $38.88 \pm 1.7$ & $46.81 \pm 1.86 \mathrm{a}^{* *} \mathrm{~b}^{* * *}$ & $42.79 \pm 1.69 \mathrm{~b}^{* * *} \mathrm{c}^{* * *}$ & $40.85 \pm 1.54 \mathrm{~b}^{* * *} \mathrm{c}^{* * *} \mathrm{~d}^{* *}$ \\
\hline
\end{tabular}

Table 11. Therapeutic and Protective Effects of Taurine on Cortisone of Pregnancy Rats Injected with ADR

\begin{tabular}{|c|c|c|c|c|c|}
\hline & $\begin{array}{c}\text { Control Group } \\
(\mathrm{n}=10)\end{array}$ & $\begin{array}{c}\text { Taurine Group } \\
\quad(\mathbf{n}=10)\end{array}$ & $\begin{array}{c}\text { Toxemic Group } \\
\quad(n=10)\end{array}$ & $\begin{array}{l}\text { Therapeutic Group } \\
(\mathrm{n}=10)\end{array}$ & $\begin{array}{c}\text { Protective Group } \\
(\mathrm{n}=10)\end{array}$ \\
\hline Cortisone & $16.93 \pm 1.06$ & $16.01 \pm 1.23 \mathrm{a}^{*}$ & $22.9 \pm 1.69 \mathrm{a}^{* * *} \mathrm{~b} * * *$ & $20.23 \pm 1.65 \mathrm{a}^{* * *} \mathrm{~b}^{* * *} \mathrm{c} * * *$ & $19.02 \pm 1.6 \mathrm{a}^{* *} \mathrm{~b} * * * \mathrm{c} * *$ \\
\hline $\begin{array}{l}\text { ata are expressed as mean } \\
\text { a refers to control group. } \\
\text { refers to Taurine group. } \\
\text { refers to ADR group. } \\
\text { refers to ADR - T group. }\end{array}$ & & $\begin{array}{l}\text { nificant }<0.05 \\
\text { ificant }<0.05 \\
\text { ly Significant }<0.01 \\
\text { highly Significant }\end{array}$ & & & \\
\hline
\end{tabular}

Regarding the hepatic impairment observed in this study and the role of taurine, showed that in Toxemic group, the liver enzymes (AST, ALT, ALP) and bilirubin were markedly elevated than control group. However, in Protective group, these elevations were significantly less than that recorded in Toxemic group and higher than Control group. On the other hand, lesser effect of taurine was observed when it was used therapeutically, where the latter enzymes showed a moderate decrease in their levels regarding toxemic group.

Seven rats treated with adriamycin during pregnancy showed marked nuclear degenerative changes with cytoplasmic vacuolization, dilatation in the sinusoidal spaces with congested blood vessels, in addition to hyperplasia in Kupffer cells. The latter pathological changes were grading as score III. These observations were also accompanied with marked decrease in the morphometry of there liver cells.
The hepato-pathological changes could be attributed to the toxicity of adriamycin on the mitochondrial membrane of liver cells, which exposed to the massive destructive effect of free radicals, which logically followed by inhibition in the synthesis of DNA and RNA in the liver tissues. The previous explanation was in harmony with the suggestion of $[43,46$, 47].

It was found that hepatocellular damage was combined with elevation of all serum liver enzymes and there is a reduction in the serum protein and albumin by injecting the rats with adriamycin [48-50].

Lipid parameters showed attractive results observed in Protective group while the lipid parameter showed a marked decrease than that recorded in Toxemic group or in Therapeutic group. These values were higher than Control group in total cholesterol, triglycerides, HDL, and VLDL respectively. 
Hyperlipidemia renal function in toxemic women or rats is usually followed with nephrotic syndrome [51,52] and causes deamination of protein in tissues [51, 53] or disturbance in the thyroid function [54] or alteration in the lipid peroxidation status $[55,56]$ and elevation of hydrogen peroxide and hydroxyl radicals' impairment on lipid metabolism [57].

Moreover, hyperlipidemia in adriamycin induced nephrosis to the significant in carnitine level in heart which lead to increament in the formation of free fatty acids [26, $46,58]$.

Hyperlipidemia per se, can induce coronary insufficiency and cardiomyopathy in toxemic pregnancy [4, 59]. Therefore, the marked hyperlipidemic pattern was observed in this work accompanied with severe cardiomyopathy score, and the decrease in morphometric nuclear area of cardiac cells recorded in toxemic pregnant rats support the observation of the same authors who considered heart failure as the main cause of death in severe Toxemic pregnancy. This terminal disease may occur directly through the toxicity or indirectly through loading the heart with massive water retention $[60,61]$ or through severe renal $[5,62]$ and hepatic impairment [46, 49, 63].

The adriamycin was considered as a strong cardiotoxic drug since more than twenty years ago $[64,65]$. The authors recorded the high affinity of cardiolipin to adriamycin, which enter the cardiac cell via passive diffusion and induce extensive fragmentation in myofibrils, ribosomal constituents and mitochondria.

Same observations were also recorded [46, 47, 58] pryingly, the main histopathological changes identified in the toxemic ADR treated rats were myofibrillar loss and cytoplasmic vacuolization, which were parallel to cardiomyopathy score 4 in stage II and in stage III recorded for them. These pathological changes were referred to many mechanisms such as sever cardiac ischemia [66] function in sarcoplasmic reticulum [26, 67], increase intracellular free radicals formation $[39,68]$ or loss of cardiac troponin from the lysised myofibrillar plasma membrane $[26,69]$.

The significant decrease in taurine concentration in serum of all toxemic pregnant rats is considered as crucial finding. It was proved that vascular resistance in pregnancy depends upon the balance between vasoconstrictors (angiotensin II, Throboxane-TXA2) and vasodilators (Prostacyline-PGI2). The latter vasodilator PGI2 synthesized by endothelium lining blood vessels and placental tissues, inhibits platelets aggregation and adherence, keeping blood vessels free of platelets and ultimately clots [70]. PGI2 was also considered as a potent vasodilator in the body [71]. Platelets on the other hand, synthesize (TXA2), a potent of platelet aggregation and vasoconstrictor, therefore, toxemia of pregnancy may represent defective in PGI2 production or a loss of response to it [72].

While taurine was considered as PGI2 stimulator [72] and a powerful antivasospastic drug [73,74]. Concomitantly, the levels of antioxidant activity (as taurine) correlate with plasma levels of PIG2 and TXA2 in pregnancy induced hypertension [63].
The nephroprotective effect of taurine was proved by many researches. Since, 1988 taurine was used to attenuate glomerulosclerosis and tubulo-interstitial fibrosis in rats with chronic puromycin aminoglycoside nephropathy [75, 76], nephropathy induced by lateral renal artery occlusion [77] or by $\mathrm{CCl}_{4}$ injection $[78,79]$ and by injection with monosodium glutamate [80] lowers the level of lipid peroxides in serum and kidney tissues. In addition, it was suggested that taurine has a nephroprotective effect against adriamycin-induced proteinuria and hyperlipidemia [57] and gentamycin-induced acute tubular necrosis [81] which was associated with nephritic syndrome [53]. The latter complication is one of the most precipitating factors of renal failure in toxemic pregnancy $[2,82]$. Moreover, it was proved that taurin has protective effect against cyclosporine-A (hypertension and nephrotoxic substance) $[20,83]$ and it relaxes contracted aorta and inhibits the phenylephrine-induced contraction of renal and mesenteric arteries, therefore the action of taurine is related to potassium channel opening [23].

All these observations strongly support the marked enhancement in the kidney function and its microscopical architecture beside the improvement in the nephropathy score and morphometry observed in toxemic pregnant rats protectively treated with taurine in this work.

The hepatoprotective effect of taurine was investigated by many authors. It was postulated that taurine has cytoprotective effects on hepatocytes under hyperoxic or hypoxic condition in the presence of $\mathrm{Ca}^{2+}[84,85]$, protects liver against the hepatotoxic effect of $\mathrm{CCl}_{4}[16,78,79]$ and monosodium glutamate $[16,80,86]$ that induced hepatocyte necrosis. Moreover, it was postulated that taurine can prevent the acute and chronic damage induced by oxidative agent by decreasing oxidative stress [87]. Furthermore, taurine protects the integrity of hepatic tissue by stabilizing the reactive oxygen species mediated lipid peroxidation and protein carbonyl formation [18] and prevents the cisplatin hepatotoxicity [19] in addition, hepatic steatosis could be ameliorated by administration of taurine [88, 89]. Moreover, it was suggested that taurine deficiency might be associated with development of cholestasis in liver of both animals and children [90].

There were marked improvements in the architecture of the hepatocytes, which were parallel to decreasing in all liver enzymes and bilirubin in the serum of toxemic pregnant rats protectively treated with taurine in this work. But the latter improvement was not obvious when taurine was used therapeutically. Supporting, the diminution in cytoplasmic vacuoles is the only difference observed in therapeutic group. However, in Protective group the main pathology is localized in score II (5) and I (2) with marked improvement in all degenerative changes (score III). Few hepatocytes showed architecture deeply stained nuclei and variable sized vacuoles. Most of the degenerated cells also suffered from either partial or complete loss of their boundaries.

The strongly suggestive hepatoprotective effect of taurine may be attributed to its inhibition effect on free radical formation or through scavenging the well formed radicals $[91,92]$. It was postulated that taurine play a role in stabilizing the liver cell membrane through controlling $\mathrm{Na}^{+}-$ $\mathrm{K}^{+}$- pump and $\mathrm{Na}^{+}-\mathrm{K}^{+}$- ATPase system therefore, it can 
protect the hepatic cells from many toxic substances like adriamycin [93, 94].

Regarding heart, the cardioprotective role of taurine was the subject for many research projects in the last decade in normal and diabetic persons. It was proved that three processes that have been implicated in ischemic injury which are impaired calcium movement; altered osmoregulation and membrane remodeling. Because taurine affects all the three processes, it seemed logical that changes in the myocardial content of taurine might affect ischemic injury $[13,95,96]$.

In 1999, It was demonstrated that taurine is able to increase calcium and the amplitude of calcium transient in both normal and diabetic cardiac myocytes [96]. In addition the effects of taurine appeared to be more pronounced in diabetic than control cells [97].

It was concluded that taurine depletion renders the heart resistance to injury caused by regional ischemia in isolated taurine-depleted rat's hearts [95]. Also taurine deficiency was considered as main pathogenomic factor in precipitating cardiomyopathy in toxemic pregnant diabetic woman [98, 99]. Also, taurine was used as cardioprotective and renoprotective drug in spontaneously hypertensive rats [100]. Moreover, the cardioprotective potential of taurine was probably due to increase of the activity of free radical enzymes or to a counter action of free radicals by its antioxidant nature or to strengthening of myocardial membrane by its membrane stabilizing property [101]

Concomitantly, in 2008 serum taurine level was used in pregnant women as early marker of hypertension and to diagnose the completion -of toxemia during pregnancy [102].

In our study there was marked improvements in the histopathological architecture, cardiomyopathy score (3 in stage $0 ; 2$ in stage 1, 2 in stage II and only 3 in stage III) and in morphometric nuclear area of the cardiac nuclei obtained in toxemic pregnant rat protectively treated with taurine.

The hypertension in experimental animal was not related to the pregnancy but was due to the toxemic effect of adriamycin. The elevation in systolic blood pressure in pregnant rats induced by adriamycin may be due to its hepatotoxicity, nephrotoxicity, hyperlipidemia, cardiotoxicity or due to its stimulating effect in T3, T4 and cortisone or all of them.

It has been suggested that there is a similarity in the mechanism(s) through which the toxemia of pregnancy in women or induced by adriamycin in pregnant rats, precipitate its pathological lesions. Therefore, adriamycin pregnant rats could be considered as a good model of complicated hypertensive pregnant women. Therefore, the significant protective effect of taurine against the different pathological lesions, observed in this work in toxemic rats, could stimulate our thinking of using it in toxemic women, specially because serum and placental taurine was found to be lower in pregnant induced hypertension toxemic women [102].

In conclusion, on the basis of these findings, we suggest that lowering in serum taurine concentration in toxemic pregnancy in rat model could be considered as one of the main pathological factors precipitating all the complications observed in toxemic pregnancy. Moreover, the successful use of taurine for management of nephropathies, hepatopathies and cardiomyopathies in toxemic rats, must attract our attention to think about to obtain evidence -based medicine data regarding taurine as early as possible (protectivel) in high risk or in suspected hypertensive pregnant women to guard against the serious maternal and neonatal complications occur in pregnancy induced hypertension.

\section{REFERENCES}

[1] Laurence, Bennett P, Brown M, In: Laurence, Bennett P, Brown M, Eds. Clinical pharmacology, $8^{\text {th }}$ ed. London: New York Press 2006; pp. 250-61.

[2] Ayman E, EL-Kenawy, Walla AM. Antihypertensive therapy on adriamycin-induced spontaneous hypertension in experimental model: biochemical and immunohisto-pathological studies. J Appl Sci Res 2006; 2: 1006-13.

[3] Lindheimer A, Hypertension in pregnancy. Hypertension 1993; 22: 127-37.

[4] Cunningham F, MacDonald P, Gant N, Eds. Common complications of pregnancy. In: Williams Obstetrics, $20^{\text {th }}$ ed. Prentice Hall International, Inc. California: USA Press 1997; pp. 594-715.

[5] Walker J. Current thoughts on pathophysiology of preeclampsia/eclampsia. In: Studd J, Ed. Progress in Obstetrics and Gynecology. Churchill Livingstone. New York: USA Press 1998; pp. 53-74.

[6] Gewirtz D. A critical evaluation of the mechanisms of action proposed for the antitumor effects of the anthracyclic antibiotic Adriamycin and daunorubicin. Biochem Pharmacol 1999; 57: 72741.

[7] Wu C, Kennedy D, Yano Y, Otani S, Matsui-Yuasa J. Thiols and polyamines in the cytoprotective effect of taurine on carbon tetracholride induced hepatotoxicity. J Biochem Mol Toxicol 1999; 13: 71-6.

[8] Sturman J. Taurine in development. Physiologic Rev 1993; 73: 119-35.

[9] Condron C, Neary P, Toomey D, Redmomd HP, Bouchier HD. Taurine attenuates calcium-dependent, Fas-mediated neutrophil apoptosis. Shock 2003; 6: 564-9.

[10] Molchanova SM, Oja SS, Saransaari P. Mechanisms of enhanced taurine release under $\mathrm{Ca}^{2+}$ depletion. Neurochem Int 2005; 47: 343 9.

[11] Satoh H. Inhibition by taurine of the inwardly rectifying $\mathrm{K}^{+}$current in guinea pig ventricular cardiomyocytes. Eur J Pharmacol 1998; 346: 309-13

[12] Wade J, Olsen J, Samson F, Nelson S, Pazdernik T. A possible role for taurine in osmoregulation within brain. J Neurochem 1988; 541: 740-5.

[13] Pastukh RC, Soloducnko V, Mozaffari M, Schoffer S. Contribution of the PI3-kinase/AKT survival pathway toward osmotic preconditioning. Mol Cell Biochem 2005; 269 : 59-67.

[14] Chen WQ, Jin H, Nguyen M, et al. Role of taurine in regulation, of intracellular calcium level and neuroprotective function in cultured: neurons. J Neurosci Res 2001; 66 : 612-9.

[15] Foos TM, Wu J. Role of taurine in the central nervous system and the modulation of intracellular calcium homeostasis. Neurochem Res 2002; 27: 21-6.

[16] Miyazaki T, Karube M, Matsuzaki Y, et al. Taurine inhibits oxidative damage and prevents fibrosis in carbon tetrachlorideinduced hepatic fibrosis. J Hepatol 2005; 43: 117-25.

[17] Borgognone M, Perez LM, Basiglio CL, Ochoa JE, Roma MG. Signaling modulation of bile salt-induced necrosis in isolated rat hepatocytes. Toxicol Sci 2005; $83: 114-25$.

[18] Tabassum H, Rehman H, Banerjee BD, Raisuddin S, Parvez S Attenuation of tamoxifen-induced hepatotoxicity by taurine in mice. Clin Chem Acta 2006; 23: 24-30.

[19] Liao Y, Lu X, Lu C, Li G, Jin Y, Tang H. Selection of agents for prevention of cisplatin-induced hepatotoxicity. Pharmacol Res 2008; 57: 125-31.

[20] Han X, Patters AB, Jones DP, Zelikovic I, Chesney RW. The taurine transporter: mechanisms of regulation. Acta Physiol 2006; $187: 61-73$. 
[21] Hall JE, Brands MW, Henegar JR. Angiotensin II and long-term arterial pressure regulation. The overriding dominance of the kidney. J Am Soc Nephrol 1999;10: 5258-65.

[22] Shennan DB. Swelling-induced taurine transport: relationship with chloride channels, anion-exchangers and other swelling activated transport pathways. Cell Physiol Biochem 2008; 21: 15-28

[23] Niu L, Zhang M, Liu Y, et al. Vasorelaxant effect of taurine is diminished by tetraethylammonium in rat isolated arteries. Eur $\mathrm{J}$ Pharmacol 2008; 280: 169-74.

[24] Chen W, Matuda K, Nishimura N, Yokogoshi H. The effect of taurine on cholesterol degradation in mice fed a highcholesterol diet. Life Sci 2004; 74: 1889-98.

[25] Hiquchi WI, Tzeng CS, Chang SJ, Chiang HJ, Liu CL. Estimation of cholesterol solubilization by a mixed micelle binding model in aqueous taursodeoxycholate lecithin: cholesterol solutions. J Pharm Sci 2008; 97: 340-9.

[26] El-Shitany NA, El-Haggar S, El-Desoky K. Silumarin prevents adriamycin-induced cardiotoxicity and nephroroxicity in rats. Food Chem Toxicol 2008; 46: 2422-8.

[27] El-Agouza I. Level of taurine in non-insulin dependent diabetic patients correlation with complication of diabetes. $8^{\text {th }}$ Scientific Congress. J Egypt Ger Soc Zool 2000; 34: 339-51.

[28] EI-Agouza I, Lashin S, Fahmi S. Sulfur containing amino acids as adjuvant therapy in IDDM. J Egypt German Soc Zool 2000; 32: 267-89.

[29] Nandhini T, Anuradha C. Inhibition of lipid peroxidation, protein glyeation and elevation of membrane ion pump activity by turine in RBC exposed to high glucose. Clin Chem Acta 2003; 336 : 129-35.

[30] Casey R, Ganq C, Joyce M, Bouchier-Hayes D. Taurine attenuate acute hyperglycemia-induced endothelial cell apoptosis, leucocyteendothelial cell interactions and cardiac dysfunction. J Vasc Res 2007; $44: 31-9$.

[31] Podjarny E, Ben-Chetrit S, Rathaus M, et al. Pregnancy-induced hypertension in rats with adriamycin nephropathy is associated with an inadequate production of nitric oxide. J Hypertens 1997; 29: 986-91.

[32] Yalow R, Berson S. Introduction and general considerations In: Odell W D, Doughaday W. H, Ed. principles of competitive protein binding. Assays JB, Lippincott Co. Philadelphia Press 1971; pp. 119.

[33] Bancrofet J, Stevens A. Theory and practice of histological techniques. Chuchil L, Ed. Inburgh-London and New York: USA Press 1977; pp. 98-115.

[34] Eissa S. New classification of histopathological changes in liver, kidney and heart. J Egypt Nat Cancer Inst 2002;15: 49-52.

[35] Portillo J, Val-Bernal J, Garijo M. Prognostic correlation of morphometric values with survival in invasive transitional cell carcinoma of the bladder. Br J Urol 1992; 70: 628-33.

[36] Fukuzawa S, Hashimura T, Sasaki M. Nuclear morphometry for improve prediction of the prognosis of human bladder carcinoma. Cancer 1995; 76: 1790-6.

[37] Peti-Peteri J, Warnock DG, Bell PD. Angiotensin II directly stimulates $\mathrm{ENaC}$ activity in the cortical collecting duct via AT1 receptors. J Am Soc Nephrol 2002; 13: 1131-5.

[38] Mukhin NA. A decreased glomerular filtration rate as a general population marker of unfavorable prognosis. Ter Arkh 2007; 79(6) : 5-10.

[39] Raza M, Alorainy MS, Alghasham AA. Evaluation of ambrein and epicoprostanol for their antioxidant properties: protection against adriamycin-induced free radical toxicity. Food Chem Toxicol 2007; $45: 1614-9$

[40] Santos NA, Bezerra CS, Martins NM, et al. Ahydroxyl radical scavenger ameliorates cisplatin induced nephrotoxicity by preventing oxidative stress, redox state unbalance, impairment of energetic metabolism and apoptosis in rat kidney mitochondria. Cancer Chemother Pharmacol 2008;18: 145-55.

[41] Kaloyanides G. Metabolic interaction between drugs and renal tubulo-interstitial cells: Role in nephrotoxicity. Kidney Int 1991; 39: $531-450$

[42] Lippuner K, Zehnder H, Casez J, Takkinen R, Descoeudres C. Effect of calcium channel blockers on calcium-phosphate metabolism in-patients with end-stage renal disease. Nephrol Dial Transplant 1996; 11: 70-4.

[43] Heibashy M, Abdel MA. Kidney and liver function tests after late dimethyl sulfoxide (DMSO) administration in rats with gentamicin induced acute renal filure. J Egypt German Soc Zool 1999; 30: 35 48.

[44] Abdel Mageid S, Heibashy M. Therapeutic and prophylactic intake of allopurinol and garlic oil in renal failure rats induced by gentamycin: Experimental studies on the liver. J Union Arab Biologists 2000; 13: 505-30

[45] Hertzan-Levy S, Fish R, Skutelsky E, et al. Glomerular basement membrane anionic sites in adriamycin nephropathy: effect of saline bading and nitric oxide modulation. Nephron 2004; 84: 354-61.

[46] You JS, Pan TL, Lee YS. Protective effects of Danshen (Salvia miltiorrhiza) on adriamycin-induced cardiac and hepatic toxicity in rats. Phytother Res 2007; 21: 1146-52.

[47] Bengudoura L, Boussenone H, Wided K, Alyane M, Rouibah H, Lahouel M. Efficiency of propolis extract against mitochondrial stress induced by antineoplasic agents (doxorubicin and vinblastin) in rats. Indian J Exp Biol 2008; 46: 112-9.

[48] Andreadou I, Sigala F, Iliodromitis EK, et al. Acute doxorubicin cardiotoxicit is successfully treated with the phytochemical oleuropein through suppression of oxidative and nitosative stress. Mol Cell Cardiol 2007; 42 : 549-58.

[49] Yagmurea M, Bas O, Mollaoglu, et al. Protective effects of redosteine on doxorubicin-induced hepatotoxicity in rats. Arch Med Res 2007; 38: 380-5.

[50] Anandakymar PP, Malarkodi SP, Sivaprasad TR, Saravanan GD. Antioxidant DL-alpha lipoic acid as an attenuator of adriamycin induced hepatotoxicity in rat model. Indian J Exp Biol 2007; 45 : 1045-9.

[51] Rabelink A, Hene R, Erkelens D, Joles J, Koomans H. Partial remission of nephrotic syndrome in-patients on long-term simvastatin. Lancet 1990; 335: 1045-6.

[52] Subashini R, Ragavendran B, Gnanapragasam A, Yogeeta SK, Devaki T. Biochemical study on the protective potential of Nardostachys jatamansi extract on lipid profile and lipid metabolizing enzymes in doxorubicin intoxicated rats. Pharmazie 2007; 62: 382-7.

[53] Pedrycz A, Wieczorski M, Czerny K. The pregnancy coexisting with experimentally induced nephrotic syndrome (NS) in rats the histological assessment of kidneys in light microscopy. Ann Univ Mariae Curie Sklodowska Med 2004; 59: 225-31.

[54] Joles A, Willekes-Koolschign N, Tol, A. Hyperlipoproteillemia in analbuminemic rats. Atherosclerosis 1991; 88: 35-47.

[55] Catala A, Zvara A, Puskas LG, Kitajka K. Melatonin-induced gene expression changes and its preventive effects on adriamycininduced lipid peroxidation in rat liver. J Pineal Res 2007; 42 : 43-9.

[56] Singh G, Singh AT, Abraham A, et al. Protectiv effects of Terminalia arjuna against Doxorubicin-induced cariotoxicity. J Ethnopharmacol 2008; 117: 123-9.

[57] Venkatesan N, Venkatesan P, Karthikeyan J, Arumugam V. Protection by taurine against adriamycin-induced proteinuria and hyperlipidemia in rats. Proc Soc Exp Biol Med 1997; 215: 158-64.

[58] Iqbal M, Dubey K, Anwer T, Ashish A, Pillai KK. Protective effects of telmisartan against acute doxorubicin-induced cardiotoxicity in rats. Pharmacol Rep 2008; 60: 382-90.

[59] Bien S, Riad A, Ritter CA, et al. The endothelia receptor bloker bosentan inhibits doxorubicin-induced cariomyopathy. Cancer Res 2007; 67: 10428-35.

[60] Dell-Torres P, Mazue G, Podesta A, Manta D, Sammartini G, Imondi A. Protection against doxorubicin-induced cardiotoxi-city in weanling rats by dexrazoxane. Cancer Chemother Pharmacol 1999; 43: 151-6.

[61] Mita M, Donthamsetty S, White B, Latendress J, Mehendale H Mechanism of protection of moderately diet restricted rats against doxorubicin-induced acute cordiotoxicity. Toxicol Appl Pharmacol 2007; 225: 90-101.

[62] Temelcos C, Hutson J. Ontogeny of the VATER kidney in a rat model. Anat Res. A Discov Mol Cell Evol Biol 2004; 278: 250-7.

[63] Walker J. Advances in the management of severe Pre-eclampisa and antihypertensive therapy In: Bonnar H, Ed. Recent Advances in Obstetrics and Gynecology. Churchill Livingstone, New York: USA Press 1988; pp. 111-24.

[64] Olson F, Mayhew E, Maslow D, Rustum Y, Szoka F. Chararcterization, toxicity, and therapeutic efficacy of adriamycin encapsulated in liposomes. Eur J Cancer Clin Oncol 1982; 18: 167-76.

[65] Rahman A, White G, More N, Schein P. Pharmacological, toxicological, and therapeutic evaluation in mice of doxorubicin entrapped in cardiolipin liposomes. Cancer Res 1985; 45: 796-803. 
[66] Estevez M, Wolf A, Schramm U. Effect of PSC 833, Verapamil and amiodarone on Adriamycin toxicity in cultured rat cardiomyocytes. Toxicology 2000; 14: 17-23.

[67] Chugun A, Temma K, Oyamada T, et al. Doxorubicin-induced late cardiotoxicity: Delayed impairment of $\mathrm{Ca}^{2+}$-handling mechanisms in the sorcoplasmic reticulum in the rat. Can J Physiol Pharmacol 2000; 78: 329-38.

[68] Siveski-Lliskovic N, Hill M, Chow D, Singal P. Probucol protects against adriamycin cardiomyopathy without interfering with its antitumor properties. Circulation NY 1995; 91: 10-5.

[69] Herman E, Lipshultz S, Rifal N, et al. Use of cardiac troponin $\mathrm{T}$ levels as an indicator of doxorubicin induced cardiotoxicity. Cancer Res 1998; 58: 195-7.

[70] Rathaus M, Podjarny E, Green J, Pomeranz A, Bernheim J. Adriamycin-related hypertension in pregnant rats: response to a thromboxane receptor antagonist. Clin Sci 1995; 88: 623-7.

[71] Speroff L, Glass R, Kase N. Prostaglandins. In: Speroff, L, Fritz M, Eds. Prostaglandin: Clinical Gynecologic Endocrinology and Infertility $3^{\text {rd }}$ ed. Williams \& Wilkins / London: UK Press 1983; pp. 307-33.

[72] Kilby M, Pipkin F, Symonds E. Pharmacological prophylaxis in pregnancy-induced hypertension. In: Studd, J, Tan SL, Chervenak FA, Eds. Churchill Livingstone, Progress in Obstetrics and Gynecology. New York: USA Press 1994; Vol. 11: pp. 53-74.

[73] McCarty M. Complementary vascular-protective actions of magnesium and taurine: rationale for magnesium taurate. Med Hypotheses 1996; 46: 89-100.

[74] McCarty M. Magnesium taurate for the prevention and treatment of pre-eclampsia/eclampsia. Med Hypotheses 1996; 47: 269-72.

[75] Law RO. The mechanisms of taurine's protective action against acute guanidine nephrotoxicity. Adv Exp Med Biol 2000; 583: 35964

[76] Andrew O, Eweka MB, MSG (Anatomy). Histological studies of the effects of monosodium glutamate on the kidney of adult Wistar rats. Int J Health 2007; 6: 65-9.

[77] McCoy R, Hill K, Ayon M, Stein J, Burk R. Oxidant stress following renal ischemia. Changes in the glutathionc redox ratio. Kidney Int 1988; 33: 812-7.

[78] EI-Agouza I, Rawi S, Lashin, S. Effect of taurine on rat liver injured by chronic carbon tetracholride treatment. Egypt J Med Sci 1995; 16: 185-98.

[79] Marucci L, Alpini G, Glaser SS, et al. Taurocholate feeding prevents $\mathrm{CCL}_{4}$ induced damage of large cholangiocytes through PI3-kinase dependent mechanism. Am J Physiol Gastrointestinal Liver Physiol 2003; 284: 290-301.

[80] EI-Agouza I, Mansour M, EI-Nasshar D. Possible ameliorative effects over food additive (mono sodium glutamate) administration in female rats. J Egypt German Soc Zool 1999; 29: 133-63.

[81] Erdem A, Gundogan N, Usubutun A, Kilinc K, Bozkurt A. The protective effect of taurine against gentamicin-induced acute tubular necrosis in rats. Nephrol Dial Transplant 2000; 15: 117582.

[82] Davidson M. Diagnosis and classification of diabetes mellitus, diagnosis and treatment. In: Mayer B, Ed. Davidson. Saunders Company: Philadelphia USA Press 1998; pp. 1-15.

[83] Hagar HH, EI Etter E, Arafa M. Taurine attenuates hypertension and renal dysfunction induced by cyclosporine A in rats. Clin Exp Pharmacol Physiol 2006; 33: 189-96.

[84] Torkunov P, Sapronov N. The action of a new taurine derivative in different variants of hypoxic states. Eksp Klin Farmakol 2000; 63: $37-40$.
[85] Schemmer P, Liang R, Kinctus M, et al. Taurine improves graft survival after experimental liver transplantation. Liver Transplant 2005; 11: 950-9.

[86] Eoin W, Jiang HW, Redmond HP, et al. Role of taurine in preventing acetaminophen-induced hepatic injury in the rat. Am J Physiol Gastrointestinol Liver Physiol 2001; 280: 1274-9.

[87] Métayer S, Seiliez I, Collin A, et al. Mechanisms through which sulfur aminoacids control protein metabolism and oxidative status. J Nutr Biochem 2008; 19: 207-15.

[88] Kerai M, Waterfield C, Kenyon S, Asker D, Timbrell J. Reversal of ethanol-induce hepatic steatosis and lipid peroxidation by taurine: a study in rats. Alcohol 1999; $34: 529-41$.

[89] Fukuda T, Ikejina K, Hirose M, Takei Y, Salo N. Taurine preserves gap junctional intercellular communication in rat hepatocytes under oxidative stress. J Gastroenterol 2000; $35: 361-8$.

[90] Hung DY, Siebert GA, Chang P, Roberts MS. Hepatic pharmacokinetics of taurocholate in the normal and cholestatic rat liver. Br J Pharmacol 2005; 145: 57-65.

[91] Waterfield C, Turton J, Scales M, Timbrell J. The correlation between urinary taurine and liver damage. Toxicology 1993; 77: 15.

[92] Dogru-Abbasoglu S, Kanbagli O, Balkan J, Cevikbas U, AykacToker G, Uysal M. The protective effect of taurine against thioacetamide hepatotoxicity of rats. Hum Exp Toxicol 2001; 20: 23-7.

[93] Kocak-Toker N, Giris M, Tulubas F, Uysal M, Aykac-Toker G. Peroxynitrite induced decrease in $\mathrm{Na}^{+}, \mathrm{K}^{+}$-ATPase activity is restored by taurine. World J Gastroenterol 2005; 11: 3554-7.

[94] Elizavora E, Nedosugova L. First experiment in taurine administration for diabetes mellitus. The effect on erythrocyte membranes. Adv Exp Med Biol 1996; 403: 583-5.

[95] Allo S, Bagby L, Schaffer S. Taurine depletion, a novel mechanism for cardioprotection from regional ischemia. Am J Physiol 1997; 273: 1956-61.

[96] Holloway C, Kotsanas G, Wendt I. Acute effects of taurine on intracellular calcium in normal and diabetic cardiac myocytes. Eur J Physiol 1999; 438: 384-91

[97] Li F, Obrosova IG, Abatan O, Tian D, Larkin D, Stuenkel EL, Stevens MJ. Taurine replacement attenuates hyperalgesia and abnormal calcium signaling in sensory neurons of STZ-D rats. Am J Physiol Endocrinal Metab 2005; 288: 29-36.

[98] Militante J, Lombardini J, Schaffer, S. The role of taurine in the pathogenesis of the cardiomyopathy of insulin-dependent diabetes mellitus. Cardiovasc Res 2000; 46: 393 - 402.

[99] Cirillo R, Sacco G, Venturella S, Giachetti A, Manzini S. Comparison of doxorubicin and MEN 10755- induced long - term progressive cardiotoxicity in the rat. J Cardiovasc Pharmacol 2000; 35: $100-8$.

[100] Dawson R, Lius S, Juny B, Messina S. Eppler B. Effects of high salt diets and taurine on the development of hyper tension in the stroke-prone spontaneously hypertensive rats. Amino Acids 2000; 19: 643-65.

[101] Shiny KS, Kumar SH, Farvin KH, Anandam R, Devadason K. Protective effect of taurine on myocardial antioxidant status in iso prenaline-induced myocardial infection in rats. J Pharm Pharmacol 2005; 57: 1313-7.

[102] El-Agouza I, Khalaf A. Serum level of taurine in pregnant toxemic hypertensive women. J Hypertens 2008 (in press). 